Jakub Koryl

Uniwersytet Jagielloński

j_koryl@poczta.onet.pl

\title{
Tradycja i rozumienie. Epistemologia hermeneutyczna w Hyperaspistes I Erazma z Rotterdamu
}

\section{Abstract \\ Tradition and Understanding. Hermeneutical Epistemology in Hyper- aspistes I of Erasmus}

The aim of this paper is to present a functional and historical-semantic analysis of the following notions: tradition (traditio), authority (auctoritas), understanding (interpretatio), explanation (sensus), and sensus communis, which appear in the hermeneutics of Erasmus of Rotterdam. In a wider perspective, the study is also an attempt at re-identifying the place of the Dutch scholar's thought within the history of hermeneutics. Contrary to what has been said to-date in studies (mainly by E.-W. Kohls, R. Stupperich, F. Krüger, and P. Walter), the hermeneutical problem, according to Erasmus, is not restricted only to exegesis or biblical philology, i.e. methods of explaining a text's meaning. In its basic form, it includes the ontology of hermeneutical experience (disregarded in this context) and the act of understanding, with its initial conditions, course and specific cognitive benefits. Therefore, this paper attempts to answer two fundamental questions. First: how did Erasmus arrive at the universal, historically mediated horizon of the process of understanding? Second, introducing the epistemological dimension, did Erasmus attribute to tradition - by cognitively appreciating it as an element essential for understanding - the ability to reveal a truth that is different to that which is verifiable by objective exegesis? The $20^{\text {th }}$ century hermeneutics of M. Heidegger, H.-G. Gadamer and R. Bultmann provide helpful terminological frames that go beyond the solely methodical character 
of understanding. The fundamental sources include those of Erasmus' texts that constituted his polemic with Martin Luther, that is De libero arbitrio, and particularly the first part of Hyperaspistes diatribae adversus Lutherum. Thanks to this choice of literature the contention between the two scholars concerning the freedom of will is here discussed from a barely known epistemological point of view.

The next subject discussed is the epistemological character of Erasmus' hermeneutics. It was supposed to help formulate specific exegetic judgements, while at the same time, it already included historicity (Geschichtlichkeit), which, according to Erasmus, was the imperative feature of understanding perceived as an epistemological-existential act. The next subject discussed is the rhetoric specificity and the cognitive value of the so-called sensus communis, which together with philological skills, constituted the indispensable research equipment of an exegete in Erasmus' opinion. In the hermeneutical reflection of Erasmus, sensus communis - unlike Luther's binding judgement (assertio) - is what makes explanation as a result of understanding only probable, not certain, and reveals how the process of understanding depends on a particular situation. Hermeneutical epistemology of Erasmus provides us, therefore, with practical knowledge that constantly includes changing circumstances and so constitutes the basis for sensus communis. Consequently, in Erasmus' thought, the Christian tradition has a cognitively privileged function of an authority that aids understanding. Thereupon, Erasmus supplements the previously adopted hermeneutical division into the Holy Scripture and its interpretation with an equally important relation between the exegetical tradition applied and the exegete that relies on it. For according to Erasmus, far from obstructing understanding, tradition actually enables it because understanding always retains its historical character. In this regard, Erasmus substantially differs from Luther. Thus, the presented hierarchy of tradition and exegete not only determines the hermeneutical stance of the Netherlandish scholar, but also methodically substantiates his scepticism of a positive epistemological stance.

The functional and semantic analysis of the notions of tradition and understanding presents Erasmus' thought as one of the early elements of the history of hermeneutics that is supposed to consider not only rules and canons of "proper" understanding, but also indicate the historical dependence and the actual process of understanding. Having problematized such cognitive relations between tradition and understanding, Erasmus set off on a similar course to that which had been crowned by H.G. Gadamer's ontological rehabilitation of prejudices (Vor-urteile).

Key words: Desiderius Erasmus, Martin Luther, hermeneutics, tradition, authority, understanding, sensus communis, De libero arbitrio, Hyperaspistes, free will, Christian scepticism. 


\section{Wprowadzenie: egzegeza - doświadczenie hermeneutyczne - dziejowość}

Miejsce myśli Erazma z Rotterdamu w rozwoju tego, co Martin Heidegger nazywał „rzeczywistą hermeneutyką” (eigentliche Hermeneutik) jako ontologiczną otwartością człowieka na świat ${ }^{1}$, wciąż jest ulokowane na odległych jej peryferiach. Niektórzy badacze, jak Rudolf Pfeiffer, a za nim Ernst-Wilhelm Kohls, otwarcie podkreślali, że w wypadku Erazma mamy do czynienia jedynie z filologią biblijną albo z tzw. teologią Pisma. W przedmiotowym temacie jego wypowiedzi - jak argumentują obaj uczeni - albo nie mają usystematyzowanego i spójnego charakteru, albo wyrażony w nich wymóg pragmatycznej, tj. egzystencjalnej lektury Pisma Świętego nie potrzebował już metodycznie zdyscyplinowanej hermeneutyki². W stanowczym tonie Kohls dodawał, że „Erazm ani nie dał, ani też nie chciał dać żadnego systemu hermeneutyki”", a nieco dalej konsekwentnie zarysowywał już egzegetyczne ramy - jedyne, w których obrębie wypada mówić o problemie rozumienia: „w odniesieniu do Erazma nie ma mowy o hermeneutyce, lecz wyłącznie o filologii biblijnej; w całości wyrasta ona z pracy egzegetyczno-teologicznej

1 M. Heidegger, Onthologie (Hermeneutik der Faktizität), Hg. von K. Bröcker-Oltmanns, Frankfurt am Main 1988, s. 14. Zob. też J. Koryl, Trudne dziedzictwo Troeltscha. Uwagi krytyczne o dwóch modelach studiów nad reformacja protestancka. Część druga: historie (konfesjonalizacja - reformacja - humanizm - hermeneutyka) i perspektywy (modernizacja), „Terminus” 2 (2013), s. 260-263.

2 R. Pfeiffer, Besprechung der von A. und H. Holborn herausgegebenen Ausgewählten Werke des Desiderius Erasmus Roterodamus, „Gnomon” 12 (1936), s. 628; E.-W. Kohls, Die Theologie des Erasmus, Bd. 1, Basel 1966, s. 140. Znamienne ponadto, że omawiając w innym miejscu historyczne precedensy współczesnych sobie nurtów w hermeneutyce filozoficznej Kohls zupełnie milczy o Erazmie, zob. E.-W. Kohls, Luther oder Erasmus. Luthers Theologie in der Auseinandersetzung mit Erasmus, Bd. 2, Basel 1978, s. 215-244.

3 E.-W. Kohls, Die Theologie des Erasmus, Bd. 1, s. 141. 
i nigdy nie powinna być od niej oddzielana"4. Pomimo to hermeneutyczny wymiar myśli Erazma, aczkolwiek jedynie w egzegetycznym, czyli gramatycznym, retorycznym lub dialektycznym znaczeniu, omawiano wielokrotnie i na ogół owocnie ${ }^{5}$, osobno wskazując także na jej znaczną, choć niebezkrytyczną zależność od ustaleń m.in. Orygenesa i św. Augustyna6.

Mimo licznych opracowań, filozoficznie, nie zaś metodycznie i egzegetycznie pojmowany problem hermeneutyczny w myśli Erazma wciąż oczekuje na rozpoznanie. Tymczasem egzegeza - jako filologicznie i retorycznie, a więc metodycznie zracjonalizowany

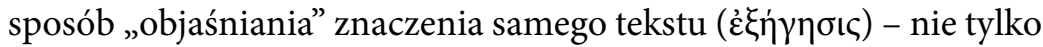
wychodziła u Erazma naprzeciw humanistycznej filologii biblijnej, ale rozsadzając jej metodyczne ograniczenia, nieśmiało, bo w nie dość jeszcze usystematyzowany sposób, zbliżała się do opisu ontologii doświadczenia hermeneutycznego z jego wstępnymi warunkami, pośredniczącą rolą tradycji, właściwym przebiegiem rozumienia

4 Ibidem, Bd. 2, s. 131.

5 Zob. J.W. Aldridge, The Hermeneutic of Erasmus, Basel 1966; J.B. Payne, Toward the Hermeneutics of Erasmus, w: Scrinium Erasmianum, ed. J. Coppens, vol. 2, Leiden 1969, s. 14-49; idem, Erasmus. His Theology of the Sacraments, Richmond 1970, s. 44-53; H. Holeczek, Humanistische Bibelphilologie als Reformproblem bei Erasmus von Rotterdam, Thomas More und William Tyndale, Leiden 1975, s. 62-137, 186-245; G. Chantraine, Érasme et Luther. Libre et self arbitre. Etude historique et théologique, Paris 1981, s. 275-306; J.H. Bentley, Humanists and Holy Writ. New Testament Scholarship in the Renaissance, Princeton 1983, s. 112-193; F. Krüger, Humanistische Evangelienauslegung. Desiderius Erasmus von Rotterdam als Ausleger der Evangelien in seinen Paraphrasen, Tübingen 1986; E. Rummel, Erasmus' Annotations on the New Testament. From Philologist to Theologian, Toronto 1986; P. Walter, Theologie aus dem Geist der Rhetorik. Zur Schriftauslegung des Erasmus von Rotterdam, Mainz 1991; A. Rabil Jr., Erasmus and the New Testament. The Mind of a Christian Humanist, Lanham 1993, s. 99-139; M. Hoffmann, Rhetoric and Theology. The Hermeneutics of Erasmus, Toronto 1994.

6 Zob. A. Godin, Érasme, lecteur d'Origène, Genève 1982, s. 125-197; Ch. Béné, Érasme et saint Augustin ou influence de saint Augustin sur l'humanisme d'Érasme, Genève 1969, s. 215-280, 372-425. 
i określonymi korzyściami poznawczymi ${ }^{7}$. Roboczego wyjaśnienia wymaga epistemologiczna funkcja takiego doświadczenia. Niderlandzki uczony konsekwentnie umieszczał swoje rozważania na rzeczony temat w kontekście poznawczym, skoro rozumienie (interpretatio), nade wszystko rozumienie Pisma Świętego, służyło nie tylko zgodnie podkreślanej przez dotychczasowych komentatorów egzystencjalnej, dla filozofii chrześcijańskiej Erazma zgoła koniecznej przemianie $e^{8}$, ale też przeoczonemu dotychczas weryfikowaniu i poszerzaniu wiedzy, a zarazem odsłanianiu i wciąż rozumnemu dowartościowaniu tego, co przekracza zdolności poznawcze człowieka. W rezultacie rozumienie w refleksji hermeneutycznej Erazma znaczy coś więcej niż zidentyfikowane przez Kohlsa "wykładanie” (Auslegung), jako „osobiste i egzystencjalne spotkanie zbawcze z Pismem" (personale und existentielle Heilsbegegnung mit der Schrift) albo „egzystencjalne obcowanie” (existentieller Umgang), a więc wymierne oddziaływanie Pisma na egzystencję, a następnie wpływ egzystencji - uprzednio poruszonej przez Pismo - na rozumienie tekstu biblijnego. Takie oddziaływanie było bowiem nie tylko pozbawione poznawczych aspiracji, nazbyt pochopnie zignorowanych przez Kohlsa w imię zasady transformatio magis quam ratio, ale również nie uwzględniało kluczowego rozróżnienia na hermeneutyczną

7 Z punktu widzenia dyskutowanego tu zagadnienia praca Dietricha Hartha z 1970 roku Philologie und praktische Philosophie. Untersuchungen zum Sprach- und Traditionsverständnis des Erasmus von Rotterdam (München 1970) więcej obiecuje, niż faktycznie dostarcza. To bowiem przegląd filozofii praktycznej Erazma jako ogniwa humanizmu renesansowego, gdzie pojęcie tradycji jest rozumiane na ogół jako przekaz (Überlieferung), a nie jako element w stosunku do rozumienia asystujący i pozytywnie niezbywalny. Gdy natomiast Harth pisze o tradycji jako o literackim przekazie, który wspomaga teraźniejszość, to tylko przygodnie i, jeśli niczego nie przeoczyłem, wyłącznie raz w nawiązaniu do słynnego powiedzenia Bernarda z Chartres o karłach siedzących na barkach gigantów (zob. ibidem, s. 17).

8 Zob. Erasmi Roterodami Paraclesis ad lectorem pium, w: Desiderius Erasmus Roterodamus, Ausgewählte Werke, Hg. von H. Holborn, A. Holborn, München 1933, s. 144-145, 1. 35-36, 1. 
interpretatio oraz mistyczną prophetia, którymi Erazm posługiwał się w dyskusji z Marcinem Lutrem'.

Chodzi tu zatem o zaakcentowanie dziejowej idiosynkratyczności doświadczenia hermeneutycznego jako aktu oraz rozumienia będącego rezultatem owego doświadczenia. W dalszej zaś perspektywie o oszacowanie wartości poznawczej dziejowo idiosynkratycznego rozumienia. Są to więc zagadnienia, które w dotychczasowych pracach poświęconych hermeneutyce, a nade wszystko epistemologii Erazma nie zostały omówione w zadowalającym stopniu. Podstawą niniejszego, jedynie wstępnego rozpoznania będzie funkcjonalna analiza pojęć rozumienia (interpretatio), tzw. zmysłu wspólnego (sensus communis) oraz autorytetu (auctoritas), którymi Erazm posługiwał się w pierwszej części polemicznego traktatu $\mathrm{Hy}$ peraspistes z 1526 roku, będącego obszerną odpowiedzią na wydaną rok wcześniej pracę De servo arbitrio Lutra.

Dla tak zakreślonej tematyki kategorią centralną, bo warunkującą treść każdego z wymienionych pojęć, będzie 'dziejowość. Nie oznacza ona tu po prostu historii, ale bezpośrednio i rozmyślnie korzysta z obcego polszczyźnie rozróżnienia, które z powodzeniem funkcjonuje na obszarze języka niemieckiego, gdzie respektowana jest subtelna różnica między „dziejami” (Geschichte), jako najogólniej rzecz biorąc pewnym atrybutem rzeczywistości, oraz „historią” (Historie),

9 E.-W. Kohls, Die Theologie des Erasmus, Bd. 1, s. 137, 182. Zob. niżej przypisy nr 16, 56 i 57. Dyskusyjność pewnych wniosków Kohlsa wynika przede wszystkim $\mathrm{z}$ faktu, że materiał źródłowy jego monografii obejmuje jedynie trzy prace Erazma, mianowicie Epistola de contemptu mundi, Antibarbari oraz Enchiridion militis christiani. Późniejsze pisma Erazma interesują autora jedynie w marginalnym stopniu. Zastanawiające skądinąd, że równie krytyczny względem hermeneutycznego potencjału myśli Erazma Pfeiffer także opierał swoją diagnozę na równie zawężonej i relatywnie wczesnej dokumentacji źródłowej, czyli na Paraclesis, Methodus, Apologia oraz Ratio verae theologiae. Wypada przy tym koniecznie dodać, że nawet tak ograniczona podstawa materiałowa nie musiała wykluczać pozytywnej identyfikacji problemu hermeneutycznego u Erazma, czego dowodem są syntezy Petera Waltera (zob. wyżej przypis nr 5) oraz Roberta Stuppericha. Zob. R. Stupperich, Erasmus von Rotterdam und seine Welt, Berlin 1977, s. 129. Zob. też niżej przypisy nr 62, 63 i 113. 
jako usystematyzowanym i naukowym wykładem takiej rzeczywistości $^{10}$. Kategorią 'dziejowości' będę posługiwać się tu w znaczeniu hermeneutycznym kompendialnie podanym przez Rudolfa Bultmanna. Geschichtlichkeit oznacza zatem nie tylko niezbywalną zależność rozumiejącej egzystencji od swoich własnych dziejów, które każdorazowo pozbawiają taką egzystencję zerowego, by tak rzec - a po Kantowsku czystego - punktu wyjścia w długim procesie rozumienia; owa Geschichtlichkeit akcentuje też pewną bezsilność egzystencji w konfrontacji z nią, a w rezultacie zakłada konstruktywną konieczność pozostawania na łasce uwarunkowania przez swoje dzieje. Ujmowana od strony własnej dziejowości rozumiejąca egzystencja jest zatem hermeneutycznie i poznawczo niewolna od zewnętrznych okoliczności i własnych, jednostkowych uwarunkowan ${ }^{11}$. Problematyzując fenomenologicznie różnicę między Geschichte oraz Historie Heidegger wprost mówi tu o „pochodzeniu” ludzkiej egzystencji (Dasein) z dziejów, czyli egzystencji, która staje się i stale przebiega $\mathrm{w}$ czasie, słowem $-\mathrm{z}$ konieczności podlega zmianie. Oznacza to zatem, że Geschichte przestaje być jedynie tym, co przeszłe, czyli oddalone w czasie i pozbawione wpływu na teraźniejszość ${ }^{12}$.

Ponadto, jak poucza Wilhelm Dilthey, w ramach istoty tego, co dziejowe (Wesen des Geschichtlichen), mieszczą się również wytwory człowieka, $\mathrm{z}$ ustalaniem wartości i ich realizacją na czele. Te natomiast tworzą razem sieć wzajemnych i ześrodkowanych na sobie

10 Na temat historii obu pojęć i dzielących je różnic znaczeniowych zob. R. Koselleck, O rozpadzie toposu „Historia magistra vitae” w polu horyzontu historii zdynamizowanej nowożytnością, w: idem, Semantyka historyczna, wstęp i opr. H. Orłowski, tłum. W. Kunicki, Poznań 2001, s. 86-99. O filozoficznej genealogii pojęcia Geschichtlichkeit w myśli niemieckiej od romantyzmu, poprzez Dilthey'a, na m.in. Heideggerze i Jaspersie kończąc zob. O.F. Bollnow, Zum Begriff der Geschichtlichkeit, w: Gegenwartsfragen der Wirtschaftswissenschaft, Hg. von H. Hunke, E. Wiskemann, Berlin 1939, s. 314-373.

11 Zob. R. Bultmann, Geschichte und Eschatologie, Tübingen 1964, s. 2-3, 141.

12 M. Heidegger, Bycie i czas, przeł., przedmową i przypisami opatrzył B. Baran, Warszawa 1994, s. 530. 
oddziaływań, co oznacza, że nie potrzebują one dla siebie ani ahistorycznej i transcendentnej miary, ani takowego uzasadnienia ${ }^{13}$. Dzięki temu kategoria 'dziejowości' stwarza dogodne warunki dla identyfikacji zależności, jakie łączą rozumienie ze „zmysłem wspólnym”. Podlegające bowiem rozumieniu historyczne wytwory człowieka - w dyskutowanym tu zakresie chodzi głównie o osąd (opinio) oraz wykładnię (sensus) - tylko dlatego są rozumiane, ponieważ zostają wyprowadzane poza wąskie ramy formułującej je jednostkowej subiektywności, a więc każdorazowo zawierają w sobie już jakiś wspólny element wszystkich takowych wytworów. Innymi słowy, jeśli jednostkowy osąd lub wykładnia jest aktem rozumienia tego, co osądza lub wykłada, to dzieje się tak dlatego, że zawsze pozostaje we wzajemnej zależności z wcześniejszymi, pośredniczącymi osądami lub wykładniami ${ }^{14}$. Jako taka 'dziejowość' sytuuje się zatem na przeciwnym biegunie względem wyizolowanych, odseparowanych, historycznie i kulturowo indyferentnych, a więc czystych aktów dyskursywnych, które w zamierzeniu m.in. Kanta miały neutralizować wielogłosowość dziejów. Tyle Bultmann, Heidegger i Dilthey.

13 W. Dilthey, Der Aufbau der geschichtlichen Welt in den Geisteswissenschaften, Hg. von B. Groethuysen, Göttingen 1992, s. 138. Karl Popper w dokładnie taki właśnie sposób opisywał stanowisko m.in. Dilthey’a, mając zapewne na myśli jego geschichtliche Welt, gdzie język jest nie tylko wytworem ludzkim, ale również to, co język wyraża, pozostaje w ramach wewnątrzświatowego powiązania świata fizycznego i świata świadomości; przedmiotowym układem, co ważne, pozbawionym pozaświatowego, obiektywnego i wiecznego uzasadnienia. Zob. K.R. Popper, Teoria obiektywna rozumienia historycznego, w: idem, W poszukiwaniu lepszego świata. Wykłady i rozprawy z trzydziestu lat, przeł. z niemieckiego i angielskiego oraz przypisami opatrzył A. Malinowski, Warszawa 1997, s. 191.

14 W. Dilthey, Der Aufbau der geschichtlichen Welt..., s. 147-148. Zob. też ibidem, s. 143. 


\section{Dziejowość interpretatio jako aktu epistemologiczno- -egzystencjalnego}

Epistemologiczne motywacje hermeneutyki Erazma zostały przez niego czytelnie zasygnalizowane już na samym początku dyskusji z Lutrem. W przedmowie do Diatryby Erazm otwarcie bowiem wyjaśniał, że kierował się przede wszystkim poznawczymi motywacjami (veritatis eliciendae studio) ${ }^{15}$. Przypuszczalnie najistotniejszą, a hermeneutycznie najbardziej doniosłą obserwacją poczynioną przez Erazma w Diatrybie było jednak powiązanie aktu rozumienia z egzystencją człowieka. „Gdyby dar proroctwa (prophetia) - jak spekulował - został przekazany byle komu, wtedy wszelkie rozumienie (interpretatio) stałoby się wątpliwe. Gdyby nikt go nie otrzymał, wówczas żadne rozumienie nie budziłoby wątpliwości" ${ }^{16}$. Innymi słowy, wobec pewnej prophetia zawodna interpretatio staje się zbędna. Wszelako prophetia, jako dar niezawodnego objaśniania tajemnic Pisma, jest dostępna wyłącznie prorokom. Kto zaś prorokiem nie jest, ten z konieczności dysponuje jedynie niepewnym rozumieniem. Dwa lata później w Hyperaspistes I owa obserwacja przybrała nieco inną, choć równie doniosłą hermeneutycznie i analogiczną funkcjonalnie postać: „gdyby prawda była otwarcie jawna, wówczas należałoby odrzucić sądy tych, którzy uprzednio rozminęli się z tym, co prawdziwe" ${ }^{\prime 17}$. Rozumienie (interpretatio) zatem, jak również bazujący na nim osąd (opinio), to dziejowo zapośredniczona i skończona dyspozycja względem rzeczywistości. Jej skończoność polega na już specyficznie ludzkim, ograniczonym, bo zawsze współokreślanym przez konkretną egzystencję i położenie człowieka, dostępie do

15 LB, IX, 1215B-C (skrót LB: Desiderii Erasmi Roterodami Opera omnia, recognovit J. Clericus, t. 1-10, Hildesheim 1961-1962. Cyfra rzymska oznacza tom, arabska kolumnę, litera alfabetu odcinek kolumny).

16 LB, IX, 1219C-D. Jeśli nie zaznaczono inaczej, wszystkie przekłady cytatów obcojęzycznych pochodzą od autora niniejszej pracy.

17 LB, X, 1263C. 
tego, co jest rozumiane. Skończoność rozumienia oznacza tu zatem trwałą zależność interpretatio od własnych dziejów, odsłania horyzont, w którym rozumienie powstaje i podlega zmianie. Dzięki temu pojęcia tradycji oraz autorytetu zyskały dla siebie znacznie szerszą funkcję niż tylko egzegetyczną.

$\mathrm{Na}$ takiej podstawie Erazm otwarcie poczynił z pozoru banalne, choć dla problemu hermeneutycznego zgoła kluczowe rozróżnienie - przedmiotem kontrowersji z Lutrem nie jest Pismo Święte, ale wyłącznie jego wykładnia (sensus) ${ }^{18}$. Rozumienie, a następnie wykładnia Pisma opiera się, zdaniem niderlandzkiego uczonego, na trzech filarach: dowodach skrypturystycznych (Scripturae divinae testimonia), rzetelnym rozumowaniu (solida ratio) oraz obdarzonej autorytetem tradycji egzegetycznej ${ }^{19}$. Wszystkie te elementy wchodzą we wzajemne relacje hermeneutyczne, ponieważ „gdy dochodzi do sporu o wykładnię Pisma (de sensu Scripturae), dawni pisarze ortodoksyjni wspierają nasze rozumienie (interpretatio)" 20 . Przedmowa do Diatryby przekonuje ponadto, że dla Erazma pojęcie tradycji nie było wyłączne ekwiwalentem kościelnego magisterium, ale pod względem funkcjonalnym obejmowało ono znacznie rozleglejszy obszar. Pozytywnie oddziałującą na rozumienie tradycję niderlandzki uczony rozmyślnie powiązał z pojęciem autorytetu (auctoritas) i takiż przydał jej atrybut, czyli właściwość, która w przedmiocie potrzeb poznawczych człowieka staje się punktem oparcia, z którego rozumienie owocnie i wymiernie korzysta. Owe zagadnienia rozwinięte zostały w pierwszej księdze Hyperaspistes, która w odróżnieniu od apologetycznej księgi drugiej, jest wykładem - nieco chaotycznym i rozwlekłym - zasygnalizowanego w Diatrybie problemu hermeneutycznego.

Przypuszczalnie z powodu skrajnie odmiennych presupozycji hermeneutycznych Erazma i Lutra w przedmiocie relacji między

\footnotetext{
18 LB, IX, 1219B.

19 LB, IX, 1218D.

20 LB, IX, 1220B.
} 
Bogiem a Słowem bożym oraz wynikającego stąd zagadnienia jasności Pisma Świętego, obaj uczeni nie tylko nie mogli odnaleźć kompromisowego stanowiska, ale w zasadzie zupełnie rozmijali się ze swoją argumentacją, czyniąc takie rozwiązanie niemożliwym. Przypisana bowiem Diatrybie próba zakwestionowania jasności Pisma, a w konsekwencji niejako obligatoryjne sięganie po odrzuconą przez Lutra tradycję egzegetyczną, wynikała, zdaniem Erazma, z nieuwagi Lutra, który miał przeoczyć fakt, że tematem ich dyskusji nie jest Pismo samo w sobie albo jego jasność, ale wyłącznie jego zróżnicowane wykładnie (interpretationes) oraz dociekania (quaestiones), generujące rozumienie tych fragmentów Pisma, w których zapisane są tajemnice Objawienia ${ }^{21}$. „Wiesz przecież - zniecierpliwiony zwracał uwagę swojemu adwersarzowi - że mówię nie o Piśmie, lecz o zagadnieniach, które $\mathrm{z}$ niego wyrastają"22.

Z drugiej jednak strony Erazm strywializował czy raczej zwyczajnie nie zrozumiał zaznaczonego na początku De servo arbitrio elementarnego rozróżnienia Lutra: „Bóg i Pismo Boga to dwie rzeczy"23. Poczyniona przez Lutra dystynkcja była dla Erazma sofistycznym kuglarstwem, które służyło jedynie zaciemnieniu i tak już niejasnego zagadnienia: „Nie będę z uwagą roztrząsać twojego rozróżnienia, gdzie oddzielasz Boga od Pisma, tak jak stwórca jest odróżniony od stworzenia. Nie wiem w jakim celu będziesz je wprowadzać"24. Motywacje Lutra były jednak zgoła przeciwne, również na planie poznawczym, od tych, które przypisywał mu Erazm. Tylko bowiem dzięki takiemu rozróżnieniu możliwe było respektowanie suwerenności Boga przed poznawczymi ambicjami człowieka. Zarazem owo rozróżnienie podkreślało pośredniczącą rolę Słowa, co miało niebagatelne znaczenie w kontekście właściwego, zdaniem

21 LB, X, 1312B; LB, X, 1264A.

22 LB, X, 1265A.

23 De servo arbitrio, Hg. von A. Freitag, w: D. Martin Luthers Werke. Kritische Gesamtausgabe, Bd. 18, Weimar 1908, s. 606, 1. 11.

24 LB, X, 1264E-F. 
Lutra, tematu teologii, czyli relacji między usprawiedliwiającym Bogiem i człowiekiem, który wprawdzie grzeszy z natury, ale zdolny jest słuchać Słowa bożego ${ }^{25}$. Rozróżnienie między Bogiem samym w sobie (Deus ipse) i Słowem Boga (verbum Dei) pokrywa się u Lutra z opozycją Boga ukrytego w swoim majestacie, naturze oraz woli (Deus absconditus) oraz Boga przyobleczonego w Słowo (Deus praedicatus). Przedmioty wskazane w pierwszych członach obu opozycji są dla człowieka niedostępne (imperscrutabilis), drugie natomiast winien on starannie badać i w nich szukać wsparcia (spectandum $e s t)^{26}$. Erazm, co Luter już zupełnie słusznie skonstatował, tego rozróżnienia nie pojął. W rezultacie wyjaśnienia z De servo arbitrio, że niejasności w wykładni Pisma biorą się z niezrozumiałych znaków językowych (signa), nie zaś z samej rzeczy oznaczanej (res), również niczego Erazmowi w konstruktywny sposób nie rozjaśniły ${ }^{27}$.

„Pismo przedstawia nam Boga i mówi o tajemnicach jego boskiej natury. W związku z tym, że mowa tam o rzeczy, której nie da się pojąć myślą, zatem i język jest $\mathrm{z}$ konieczności w pewnej mierze niezrozumiały. Zaimkiem jego nie posługuję się tak, jak ty przypuszczasz, że należy się posługiwać, czyli w odniesieniu do Pisma, ale do Boga. [...] Sam obraz oraz rzecz na nim wyrażona odpowiadają sobie nawzajem", jak Erazm komentuje w Hyperaspistes ${ }^{28}$. Przypuszczalnie jest to najbardziej jaskrawe miejsce, w którym myślenie Erazma i Lutra biegunowo oddala się od siebie. Pogląd Erazma, który obstawał przy pełnej, substancjalnej referencjalności między Bogiem

25 Zob. Enarratio Psalmi LI, Hg. von A. Freitag, w: D. Martin Luthers Werke. Kritische Gesamtausgabe..., Bd. 40-2, s. 328, 1. 1-3.

26 De servo arbitrio..., s. 685-686, 1. 14-17, 25-31, 1-2. Zob. też C. Augustijn, Hyperaspistes 1: Die Lehre der 'claritas scripturae' bei Erasmus und Luther, w: idem, Erasmus. Der Humanist als Theologe und Kirchenreformer, Leiden 1996, s. 268-271; G. Bader, Assertio. Drei fortlaufende Lektüren zu Skepsis, Narrheit und Sünde bei Erasmus und Luther, Tübingen 1985, s. 155-156; A. Beutel, In dem Anfang war das Wort. Studien zu Luthers Sprachverständnis, Tübingen 2006, s. 246-250.

27 De servo arbitrio..., s. 606, 1. 22-24; LB, X, 1263B.

28 LB, X, 1264F-1265A. 
a Pismem Świętym, staje się bardziej zrozumiały w świetle wcześniejszego o kilka lat komentarza do Prologu Janowego. Wprawdzie niderlandzki uczony, podobnie jak Luter, rozróżnił tam dwa porząd$\mathrm{ki}$, słowa wewnętrznego (verbum internum) i słowa zewnętrznego (verbum externum), ale konsekwentnie podkreślał, że tożsame ze sobą są one tylko w odniesieniu do Boga. Innymi słowy, fundamentalne rozróżnienie Lutra na Boga i Słowo boże pozbawione było uzasadnienia, skoro w wypowiedzianym przez Boga Słowie ( $\lambda$ ó o \ / verbum / sermo) bez uszczerbku wyraża się cała mądrość myśli bożej ${ }^{29}$.

W rezultacie Erazm zupełnie nie pojął również doktryny Lutra o wewnętrznej, a zwłaszcza zewnętrznej jasności Pisma Świętego, ponieważ każdorazowo i w zgodzie z własnym stanowiskiem hermeneutycznym odnosił on kategoryczne wypowiedzi Lutra do samego Boga, mimo że dotyczyły one odmiennego odeń Pisma Świętego. Ironizując na temat owego rozróżnienia, które zdaniem Erazma prowadziło na poznawcze manowce, stwierdzał on: „I znowu, twoje rozróżnienie na wewnętrzną i zewnętrzną niejasność [Pisma] służy nie czemu innemu, jak tylko temu, byś ty mógł się wymknąć, a nas zamęczyć swoją gadatliwością"30. W następstwie nieporozumień po obu stronach, dyskusja o wolnej woli, a szerzej także spory między poszczególnymi denominacjami protestanckimi ${ }^{31}$, była u swoich podstaw konfliktem interpretacji - de interpretatione contentio est ${ }^{32}$. „Nasze rozumienie tobie nie odpowiada - podkreślał Erazm - lecz twoje rozumienie nie

29 Zob. J. Koryl, In principio erat sermo. Erazma z Rotterdamu rozważania nad znaczeniem pojęcia logos w pierwszym wersecie Prologu Ewangelii św. Jana, w: Studia Rhetorica, red. M. Choptiany, W. Ryczek, Kraków 2011, s. 113-121. Tam również szczegółowa dokumentacja źródłowa. Zob. też G. Bader, Assertio..., s. 158-161; A. Beutel, In dem Anfang war das Wort..., s. 87-88 i dalej.

30 LB, X, 1265B. Zob. też LB, X, 1306D.

31 Zob. LB, X, 1263D, 1264A, 1308B-C.

32 LB, X, 1294D. Erazm w innych miejscach Hyperaspistes I wielokrotnie zwracał Lutrowi uwagę, że ich spór o wolną wolę jest właśnie konfliktem interpretacji. Zob. LB, X, 1280A, 1283E, 1284A, 1290C, 1298E, 1302F. 
odpowiada nauce Kościoła”, a nieco dalej konkludował: „oba stanowiska odrzucają rozumienie drugiej ze stron"33.

Ze względu na dziejowy charakter interpretatio, wprowadzone przez Lutra rozróżnienia nie miały dla Erazma, bo i mieć nie mogły, uniwersalnie wiążącej mocy, ani tym bardziej separatystycznego znaczenia. Przeciwnie dla Lutra, który w miejsce owych interpretationes posługiwał się sądem wiążącym (assertio), w jego języku oznaczającym „konsekwentne obstawanie, stanowcze twierdzenie, wyznawanie, bronienie, a także niezłomne trwanie"34. Taki wybór miał u Lutra ważne uzasadnienie. Podstawą niezrozumiałych dla Erazma asercji teologicznych była bowiem protestancka zasada wyższości Pisma, która programowo uwalniała egzegezę od dowolności i dzięki temu czyniła polemiczny dyskurs teologii, odtąd już obligatoryjnie jako „konfrontacja asercji”, narzędziem wyznaniowo konstruktywnym ${ }^{35}$. Zdaniem Lutra pojęcie autorytetu jako tradycji kościelnej miało proteuszową naturę, a co za tym idzie nie czyniło zadość wyznaniowym potrzebom asercji ${ }^{36}$. Erazm natomiast już w Ratio verae theologiae

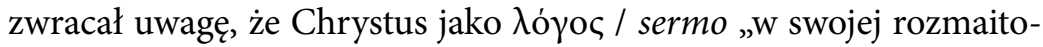
ści życia i nauk" objawia się w rzeczywistości właśnie jako Proteusz ${ }^{37}$.

33 LB, X, 1294E; LB, X, 1318A. Zob. też LB, X, 1298C-D; LB, X, 1316A-B; LB, $\mathrm{X}, 1319 \mathrm{D}$.

34 De servo arbitrio..., s. 603, 1. 12-13.

35 Określenie modelowej, według Lutra, dyskusji teologicznej jako Assertionenkonfrontation zaczerpnąłem z monografii Dietricha Kerlena. Zob. D. Kerlen, Assertio. Die Entwicklung von Luthers theologischem Anspruch und der Streit mit Erasmus von Rotterdam, Wiesbaden 1976, s. 305-317 (odnośnie bliższej charakterystyki terminu Assertionenkonfrontation zob. ibidem, s. 307); G. Bader, Assertio..., s. 161-170.

${ }^{36}$ De servo arbitrio..., s. 604, 1. 19-20. Na temat znajomości i stosunku Lutra do tradycji egzegetycznej zob. G. Ebeling, Evangelische Evangelienauslegung. Eine Untersuchung zu Luthers Hermeneutik, Tübingen 1991, s. 141-269; W.-D. Hauschild, Die Bewertung der Tradition in der lutheranischen Reformation, w: Kanon - Schrift - Tradition, hg. von W. Pannenberg, Th. Schneider, Freiburg im Breisgau 1992, s. 197-200, 208-225.

37 Ratio seu methodus compendio perveniendi ad veram theologiam, w: Desiderius Erasmus Roterodamus, Ausgewählte Werke..., s. 214, 1. 30-33. Zob. też J.K. McConica, Erasmus and the Grammar of Consent, w: Scrinium Erasmianum..., 
W konsekwencji sama rzeczywistość nabiera istotnie hermeneutycznych znamion. Ma ona bowiem logocentryczny charakter, a jej rozumienie, głównie za pośrednictwem Pisma, opiera się na dialogu, dzięki któremu człowiek może wchodzić z rzeczywistością w poznawczo owocną, choć wymagającą wysiłku hermeneutycznego relację.

W Diatrybie Erazm rozwinął zalążkowo obecny już w Paraclesis retoryczny wymóg dostosowania (accommodatio) języka ze względu na jego niezbywalne, rzeczowe i osobowe zróżnicowanie. O ile pierwotnie właściwy zakres owej accommodatio nie został jeszcze dokładnie doprecyzowany, odnosiła się ona bowiem do Erazmowego pojmowania chrześcijaństwa jako philosophia Christi ${ }^{38}$, o tyle w Diatrybie przeniesiono ją już na grunt tego, co dystynktywne w języku samej Biblii. Odtąd tak dostosowany język biblijny stał się medium, które w hermeneutyczny par excellence sposób pośredniczy między bezczasowym znaczeniem prawdy bożej i jej już dziejowym, skończonym rozumieniem. „Specyfika języka biblijnego - czytamy w Diatrybie - polega na tym, że sam dostosowuje się on do naszej wykładni. [...] Nie prowadzi to jednak do zmian w naturze Boga, ale wyrażając się w taki sposób Słowo boże porozumiewa się z naszą niemocą i ociężałością"39. Kilka lat wcześniej, objaśniając swój

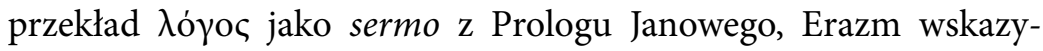
wał, przez wzgląd na Chrystusa, na logocentryczną, a w rezultacie

vol. 2, s. 90-92; G. Chantraine, Mystère et philosophie du Christ selon Erasme. Etude de la lettre à P. Volz et de la Ratio verae theologiae (1518), Namur 1971, s. 297-298.

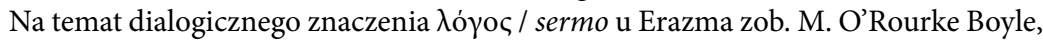
Erasmus on Language and Method in Theology, Toronto 1977, s. 8-31; J. Koryl, In principio erat sermo. Erazma $z$ Rotterdamu rozważania nad znaczeniem pojęcia logos..., s. 97-102.

38 Zob. Erasmi Roterodami Paraclesis ad lectorem pium..., s. 141-142, 1. 35-36, 1-2. Zob. też Institutio oratoria, XI, 1, 2.

39 LB, IX, 1218A-B. Szerzej na temat accomodatio jako pospołu retorycznej i teologicznej zasadzie hermeneutyki Erazma zob. P. Walter, Theologie aus dem Geist der Rhetorik..., s. 42-52. Tutaj i dalej pojęciem „logocentryczności” posługuję się za Georgem Steinerem, jako „przymierzem między słowem a światem”. Zob. G. Steiner, Rzeczywiste obecności, przeł. O. Kubińska, Gdańsk 1997, s. 79, 102. 
hermeneutyczno-dialogiczną naturę rzeczywistości: „wypowiedziany został w najprostszy i najbardziej nam bliski sposób, gdy przyjmując ludzkie ciało przemówił do nas zwyczajem ludzi (humano more)" 40 .

Boskie mówienie humano more, co raz jeszcze należy podkreślić, nie oznaczało u Erazma 'w substancjalnie niereferencjalny sposób z myślą bożą, nie było zatem mówieniem, które narusza tożsamość boskiej myśli i słowa. Taka niereferencjalność zachodzi tylko i wyłącznie w relacji między ludzką myślą i ludzką mową, między ludzkim verbum internum i verbum externum. W zestawieniu $\mathrm{z}$ relacją dwóch boskich logosów (wewnętrznego i wypowiedziane-

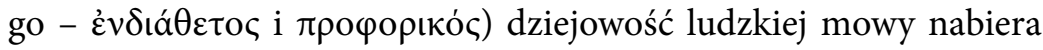
jeszcze jednej ważnej cechy - sermo człowieka ma charakter akcydentalny. W rezultacie język, $\mathrm{z}$ pomocą którego człowiek próbuje zrozumieć naturę Boga, jest dalece niedoskonały i owocuje zmiennością kolejnych wykładni. Pomimo to nigdy nie narusza on tożsamości substancji boskiej, ale względem niej jedynie się oddala lub zbliża $^{41}$. Dla problemu hermeneutycznego jest szczególnie doniosłe, że poszukując w komentarzu do Prologu Janowego dystynktywnej cechy ludzkiej mowy, Erazm zidentyfikował ją jako coś par excellence dziejowego, czyli 'mowę zmienną w czasie i dostosowaną do chwili' (sermo temporarius), a więc coś, co jest w drodze, czyli stale i niezbywalnie pozostaje zapośredniczone i uwarunkowane przez swoją własną dziejowość. Tak pojmowana właściwość ludzkiej mowy staje się jeszcze bardziej wyrazista w kontrastywnym zestawieniu z wiecznością mowy Boga (sermo aeternus), a więc z cechą, która neutralizuje wielopostaciowość, wielogłosowość i akcydentalność tego, co dziejowe ${ }^{42}$.

W ostatniej, czwartej księdze Ecclesiastes, gdzie niderlandzki uczony omawiał m.in. zagadnienie bezczasowości prawa bożego,

\footnotetext{
40 LB, IX, 119E.

${ }^{41}$ Zob. LB, IX, 117B-C.

42 Zob. LB, IX, 117B-C.
} 
z retorycznego wymogu accommodatio zostały wyciągnięte końcowe wnioski dla Erazmowej epistemologii hermeneutycznej, a w jej obrębie - dla skończenie-dziejowego charakteru rozumienia. Dzięki bowiem zestawieniu z wolnym od dziejowego zapośredniczenia porządkiem boskim omawiana tu zasada dziejowości rozumienia zyskała dla siebie przejrzystą i nad wyraz kontrastywną postać: „tak jak prawo Boga zawsze pozostaje takie samo, tak też wola Boga jest niezmienna. Jednakowoż w zależności od czasów i osób jest przedstawiana w zróżnicowany sposób” ${ }^{33}$. Z takiego porównania, które wprawdzie zostało przez Erazma zwerbalizowane dopiero pod koniec życia, ale którego konsekwencje znalazły praktyczne zastosowanie już w dyskusji z Lutrem, jasno wynika, że uniwersalna, normatywna i asertoryczna moc interpretatio, a w rezultacie także moc bazującej na niej opinio, została znacząco ograniczona.

Ukształtowane dzięki treningowi krasomówczemu, a następnie podniesione do rangi zasady hermeneutycznej uwrażliwienie Erazma na to, co zmienne i dostosowane do swojego czasu, było, jak przekonująco wykazał m.in. Peter Walter, czymś wówczas na taką skalę bezprzykładnym ${ }^{44}$. Właściwym wyrazem owej wrażliwości historycznej była świadomość własnej skończoności, a więc świadomość znacznie zredukowanej autonomii w obliczu nadrzędnej i całościowo ujmowanej tradycji. Była ona zatem zalążkową formą w pełni opisanej i funkcjonującej w XIX stuleciu świadomości histo-

43 Ecclesiastes sive de ratione concionandi (Libri III-IV), ed. J. Chomarat, w: Opera omnia Desiderii Erasmi Roterodami, ord. 5, t. 5, Amsterdam 1994, s. 320, 1. 190-191. Zob. też J. Chomarat, Grammaire et rhetorique chez Erasme, vol. 2, Paris 1981, s. 1107-1113.

44 P. Walter, Humanistische Einflüsse auf die Entstehung der Dogmatik? Ein Beitrag zur Vorgeschichte einer theologischen Disziplin, w: Dogma und Glaube. Bausteine für eine theologische Erkenntnislehre. Festschrift für Bischof Walter Kasper, Hg. von E. Schockenhoff, Mainz 1993, s. 65-68; idem, Theologie aus dem Geist der Rhetorik..., s. 81-82, 88-93, 95. Zob. też G.B. Winkler, Erasmus von Rotterdam und die Einleitungsschriften zum Neuen Testament. Formale Strukturen und theologischer Sinn, Münster 1974, s. 136-149. 
rycznej, z którą stanowisko hermeneutyczne Erazma łączą trzy podstawowe zasady: po pierwsze, przekonanie o dziejowym zapośredniczeniu i zmienności wszelkich przejawów ludzkiej aktywności (na czele z owocami kształcenia humanistycznego, czy szerzej - kulturą w jej etymologicznym znaczeniu); po drugie, sprzeciw wobec takiej dogmatyki oraz racjonalności, które mają zunimorfizowany i ahistoryczny charakter; wreszcie po trzecie, postawa sceptyczna jako wyraz filozofii zdrowego rozsądku. O ile jednak wnioski dziewiętnastowiecznych protagonistów historyzmu i teoretyków świadomości historycznej odnośnie niezbywalnego, dziejowego zapośredniczenia kultury mogły generować pewne poczucie poznawczego przygnębienia albo nawet rezygnacji ${ }^{45}$, o tyle protohistorycystyczne stanowisko Erazma na dobrą sprawę uchodzi takim negatywnym implikacjom. Trudno tu bowiem utrzymać zarówno wysunięte przez Lutra oskarżenia o klasyczny sceptycyzm, jak i kierowane pod adresem Erazma dwudziestowieczne podejrzenia o adogmatyczne albo modernistyczne traktowanie chrześcijaństwa ${ }^{46}$. Wydobycie dziejowego atrybutu kultury, co bodaj najwyraźniej widać w wyżej przywołanym za Ecclesiastes zestawieniu, nie było u Erazma równoznaczne ze zniesieniem bezczasowego dlań wzorca. Że jego teologia ma wyraźnie chrystocentryczny charakter, a osoba Chrystusa spełnia w niej przede wszystkim egzemplaryczną, tj. wzorcową właśnie rolę, to przecież właściwości Erazmowego myślenia od dawna dobrze znane i starannie opracowane ${ }^{47}$. W praktyce takie właśnie, jedynie protohistorycystyczne, bo niepozbawione jeszcze swojego bezczasowego

45 Zob. H. Schnädelbach, Filozofia w Niemczech 1831-1933, przeł. K. Krzemieniowa, Warszawa 1992, s. 62-72; idem, Wprowadzenie. O rozumności historii i historyczności rozumu, w: idem, Rozum i historia. Odczyty i rozprawy 1, przeł. K. Krzemieniowa, Warszawa 2001, s. 10-15.

${ }_{46}$ Zob. J. Koryl, Trudne dziedzictwo Troeltscha. Uwagi krytyczne o dwóch modelach studiów nad reformacja protestancką. Część pierwsza: pojęcia (ekumenizm irenizm - tolerancja) i doktryny, „Terminus” 2 (2013), s. 206-208.

${ }_{47}$ Zob. choćby E.-W. Kohls, Die Theologie des Erasmus, Bd. 1, s. 98-115, 155-157; P. Walter, Theologie aus dem Geist der Rhetorik..., s. 54-67; J. Domański, 
wzorca, stanowisko hermeneutyczne Erazma wymagało, by porzucić pretensje do trwałego i normatywnego charakteru jednostkowych orzeczeń. W rezultacie wyraźne odróżnienie Pisma Świętego od jego ludzkich wykładni stało się konieczne.

\section{Wartość poznawcza „zmysłu wspólnego” (sensus communis)}

Zasygnalizowane w Diatrybie rozróżnienie na Pismo i jego wykładnię zostało co do słowa powtórzone w Hyperaspistes $I^{48}$. Erazm ponownie związał rozumienie z dziejowym sposobem bycia człowieka, precyzując jednak w protohistorycystyczny sposób, że w odróżnieniu od proroka czlowiek pozbawiony charyzmatu Ducha Świętego dysponuje jedynie językiem jako gramatycznym systemem znaków oraz rozsądkiem, a ściślej tzw. zmysłem wspólnym (sensus communis $)^{49}$. Z wypowiedzi Erazma wynika, że kilkanaście razy powtarzane w Hyperaspistes I pojęcie sensus communis rozumiał on na sposób perswazyjny i retoryczny, nie zaś tak jak Arystoteles i Akwinata, dla których sensus communis oznaczał naturalny dla człowieka wspólny rdzeń wszystkich zmysłów, który pozwala doświadczać, dla przykładu, jabłko jako jabłko, mimo że jednocześnie podlega ono odmiennym zmysłom wzroku, powonienia, smaku i dotyku, a nawet słuchu ${ }^{50}$. Erazm bowiem, gdy wskazywał na sensus communis,

Erazm i filozofia. Studium o koncepcji filozofii Erazma z Rotterdamu, wyd. 2, Warszawa 2001, s. 209-224.

48 LB, X, 1310F.

49 LB, X, 1300B, 1300E.

50 Zob. Arystoteles, O duszy, w: idem, Dzieła wszystkie, t. 3, przekłady, wstępy i komentarze P. Siwek, Warszawa 2003, s. 111-117 (III, 1-2; 425a-427a); Tomasz z Akwinu, Traktat o Bogu. Summa teologii, kwestie 1-26, przekład i komentarze G. Kurylewicz, Z. Nerczuk, M. Olszewski, Kraków 2001, s. 20 (I, q. 1, a. 3 ad 2). $\mathrm{Na}$ temat retorycznego znaczenia sensus communis i jego hermeneutycznych impli- 
nierzadko wespół z umiejętnościami filologiczno-językowymi, miał na myśli wprawdzie specyficznie ludzką umiejętność, ale oznaczającą wspólny jedynie pewnym ludziom obszar reguł albo prawd przyjętych przez nich jako obowiązujące $\mathrm{w}$ danej sprawie. Istotną cechą tak rozumianego „zmysłu wspólnego” jest zatem jego nabywana i nadawana, uwarunkowana dziejowo wartość poznawcza. W rezultacie wiedza, jaką rozporządza sensus communis, nie ma charakteru uniwersalnego i dziejowo indyferentnego. To już nie naturalny sposób bierno-receptywnego postrzegania rzeczywistości, ale pewien rezerwuar wiedzy - człowiekowi dostępnej tylko dzięki określonym umiejętnościom - oraz typowe dla niej usposobienie względem rzeczywistości.

Wspólnotowy charakter tego zmysłu, co istotne, kształtowanego, jak podkreślał już Kwintylian, a nie nabywanego naturalnie i niejako z przyrodzenia ${ }^{51}$, wskazuje raczej na wspólne uznawanie określonych reguł niż na wspólne podleganie niezawisłym od człowieka naturalnym zasadom ${ }^{52}$. Należy ponadto pamiętać, że funkcjonalnym synonimem dla sensus communis była u Kwintyliana wspólnota posługiwania się zrozumiałym językiem (communis loquendi consuetudo), służącym perswazji, a nade wszystko nauczaniu (docere) człowieczeństwa, które poznawszy swój ograniczony dostęp do tego, co prawdziwe, za materię swojego działania przyjmuje to, co prawdopodobne ${ }^{53}$. Brak czy raczej nierespektowanie społecznie

kacji zob. H.-G. Gadamer, Prawda i metoda. Zarys hermeneutyki filozoficznej, przeł. B. Baran, Kraków 1993, s. 51-55.

${ }_{51}$ Zob. Institutio oratoria, I, 2, 20. Sama retoryka to, zdaniem Kwintyliana (X, 2, 22), właśnie zmysł wspólny oparty ma modelowym i prawdziwie kanonicznym charakterze wymowy. Wspólnotową, a ściślej powszechną specyfikę sensus communis podkreśla Giambattista Vico, nazywając go w Nauce nowej takim „poglądem”, który jest „podzielany powszechnie przez cały stan, cały lud, cały naród albo cały rodzaj ludzki”, G. Vico, Nauka nowa, przeł. J. Jakubowicz, oprac. i wstępem poprzedził S. Krzemień-Ojak, Warszawa 1966, s. 88.

${ }^{52}$ Zob. LB, X, 1299E, 1300A, 1300D, 1305D, 1305E-F, 1306D, 1308B, 1309E, 1316B-C, 1319D.

53 Institutio oratoria, XII, 1, 19. Zob. też ibidem, II, 15, 18; II, 15, 31. 
przyjętego sensus communis Cyceron otwarcie uznawał za największą wadę wymowy ${ }^{54}$. Znakomitą, par excellence retoryczną, a zarazem wskazującą na specyficznie poznawcze funkcje wykładnię tego pojęcia podał w połowie XVI stulecia Erazm Gliczner, komentując jednocześnie stosowny passus z Kwintyliana: „żadnej wiadomości o rzeczach ten człowiek nie może sobie nabyć albo naspiżować, który sam tylko w kącie mięszka, nie mając żadnych schadzek albo towarzystwa z ludźmi. Nic też nie może mieć rozsądku [tj. sensus communis - J.K.], bo rozsądek $\mathrm{z}$ wiadomości urasta, a wiadomość z pospolitowania między ludzi siły bierze, gdy się kto między ludźmi schowa, z których rzeczy bacząc, wszystko sobie zgromadza a w pamięć chowa, w czym potem mądrym się stać musi" ${ }^{55}$.

W perspektywie poznawczej właściwym kryterium, które określa wartość sensus communis, nie jest prawda, rozumiana jako system regulowany przez naukową metodę i obiektywne narzędzia falsyfikacji sądów, ale jedynie stale wymagające i podlegające perswazji prawdopodobieństwo. Jako zmysł istotnie wspólny, bo opierający się na wzajemnej perswazji $\mathrm{w}$ miejsce panowania dziejowo indyferentnych regul, sensus communis otwiera pole dla tradycji, która w rozumieniu spełnia kluczową, bo asystującą rolę. Jako taki sensus communis wydatnie dookreśla skończenie-dziejowy charakter rozumienia. „Jeśli biegłość językowa oraz zmysł wspólny - retorycznie zapytuje Erazm - wystarczają do jasnego rozumienia Pisma, to dlaczego w czasach św. Pawła ludziom mówiącym [różnymi] językami potrzebni byli prorocy?" 56 . Interpretatio dotyczy więc dziejowej, typowo ludzkiej, z wszelkimi jej ograniczeniami, wykładni Pisma; prophetia natomiast, jako wysoce specyficzna postać interpretatio, mistycznego rozumienia jego tajemnicy ontologicznej, a więc

54 Zob. De oratore, I, 12. Zob. też ibidem, II, 68. Drugą z wypowiedzi Cycerona powtórzył z aprobatą Kwintylian (Institutio oratoria, VIII, Proemium, 15).

55 E. Gliczner, Książki o wychowaniu dzieci, w: Wybór pism pedagogicznych Polski doby odrodzenia, oprac. J. Skoczek, Wrocław 1956, s. 318. Komentowany tu fragment z Institutio oratoria Kwintyliana podaję wyżej, w przypisie nr 51.

56 LB, X, 1307D. 
takiego rozumienia, które jest pozbawione jakichkolwiek implikacji poznawczych i mieści się na poziomie samego istnienia radykalnie odmiennego od zdolności dyskursywno-poznawczych oraz nie jest, tak jak właściwa interpretatio, regulowane przez sensus communis ${ }^{57}$. W przeciwieństwie zatem do hermeneutycznej interpretatio, podlegającej nie tylko określonym i zracjonalizowanym procedurom egzegetycznym, ale nade wszystko idiosynkratycznym uwarunkowaniom, prophetia odnosi się u Erazma do pozadyskursywnej, mistycznej medytacji, w najlepszym zaś razie do apofatycznego jedynie trybu orzekania.

Wobec powyższego należy raz jeszcze przyjrzeć się przywołanej na początku diagnozie Kohlsa, wedle której egzegeza Erazma była pozbawiona poznawczych aspiracji. Nieścisłość, a z pewnością dyskusyjność takiej oceny polega bowiem na tym, że Kohls przenosił na cały obszar Erazmowej refleksji nad wykładaniem Pisma - obejmującej odmienne porządki prophetia oraz interpretatio - dwie sformułowane przez siebie hierarchie. Pierwszą z nich jest nadrzędność tajemnicy (Mysterium) nad jej egzegetycznym opanowaniem (exegetische Bewältigung) i teologicznym doń dostępem (theologischer $\mathrm{Zu}$ griff), druga natomiast akcentuje pierwszeństwo tego, co egzystencjalne (das Existentielle) nad nauką (Wissenschaft) ${ }^{58}$. Tymczasem, jak wolno sądzić na podstawie wypowiedzi niderlandzkiego uczonego, obie hierarchie w pełni sprawdzają się dopiero w odniesieniu do rozumienia tajemnicy Pisma (Scripturae mysticae interpretatio), czyli do prophetia właśnie. Co więcej, nie rozróżniwszy obu porządków rozumienia - mistycznej prophetia oraz hermeneutycznej interpretatio, względnie też „zasady egzystencji oraz zasady poznania” - Kohls

${ }^{57}$ Zob. LB, X, 1307F. Na temat pozbawionego desygnatu znaczenia tego wysoce specyficznego pojęcia, jakim jest „tajemnica ontologiczna”, zob. G. Marcel, Być i mieć, przeł. P. Lubicz, Warszawa 1986, s. 86-87, 100-101; idem, Tajemnica bytu, tłum. M. Frankiewicz, przedmowa K. Tarnowski, Kraków 1995, s. 215-227. Zob. też K. Tarnowski, Ku absolutnej ucieczce. Bóg i wiara w filozofii Gabriela Marcela, Kraków 1993, s. 58-69.

58 Zob. E.-W. Kohls, Die Theologie des Erasmus..., Bd. 1, s. 127-128, 141-143. 
na dobrą sprawę musiał przeoczyć poznawczą wartość rozumienia jako źródła wiedzy ${ }^{59}$. Jeśli bowiem, jak argumentuje Kohls, w wypadku Erazmowej Schriftauslegung można mówić o jakiejś „poznawczej chwili", to ma ona charakter zdecydowanie bardziej medytacyjny i egzystencjalny niż dyskursywny i zarazem noetyczny. Zdaniem Kohlsa bowiem treść tego, co ma być poznane w trakcie lektury Pisma, pokrywa się, na drodze modlitwy i medytacji oraz na prawach egzystencjalnego spotkania, z samym aktem poznania. Wówczas, a mówiąc już słowami samego Erazma, którego Kohls cytuje na poparcie swojego wywodu, mamy do czynienia z pozadyskursywnym, już duchowym poznaniem Pisma (spiritualis scripturarum cognitio $)^{60}$.

Ujmowany w taki sposób, poznawczy wymiar rozumienia ma zatem wysoce osobliwy charakter. 'Rozumieć' bowiem nie oznacza tu noetycznej czynności gromadzenia wiedzy, ale potrzebę samopoznania etycznego ${ }^{61}$, które dokonuje się w biblijnym zwierciadle i jako takie służy, zdaniem Roberta Stuppericha, odnowieniu siebie, czy wręcz stawaniu się kimś innym dzięki otwartości na Słowo

59 Zob. ibidem, s. 179.

${ }^{60}$ Ibidem, s. 182. Zob. też ibidem, s. 139-140, cytowany tam przez Kohlsa fragment pochodzi z Enchiridionu (Desiderius Erasmus Roterodamus, Ausgewählte Werke..., s. 34, 1. 32). W świetle powyższej wypowiedzi (jak również tych przytoczonych wyżej w przypisach nr 2, 3, 4 i 9) wypada zwrócić uwagę na zastanawiającą niekonsekwencję pojęciową Kohlsa, która jest tym bardziej frapująca, jeśli wziąć pod uwagę jego jednoznacznie negatywną diagnozę hermeneutycznego potencjału myśli Erazma. Otóż pojęcie existentielle Heilsbegegnung, zupełnie kluczowe u Kohlsa w opisie Erazmowego rozumienia Pisma, jest niczym innym, jak tylko kalką jednej $\mathrm{z}$ podstawowych kategorii w dykcjonariuszu hermeneutyki Rudolfa Bultmanna, którą jest existentielle Begegnung (zob. R. Bultmann, Geschichte und Eschatologie..., s. 133-134 oraz niżej przypis nr 122), hermeneutyki w decydującym stopniu zbudowanej przecież na przełomowym dla egzystencjalnego sproblematyzowania „rozumienia” \$32 Bycia i czasu Martina Heideggera. To zagadnienie wymaga jednak osobnego rozpoznania, które przekracza ramy niniejszego opracowania.

${ }_{61}$ Szerzej na temat noetyczno-etycznych aspektów epistemologii Erazma zob. M. Hoffmann, Erkenntnis und Verwirklichung der wahren Theologie nach Erasmus von Rotterdam, Tübingen 1972, s. 101-103. 
biblijne. Na tym nie koniec. Dla postępów etycznego samopoznania noetyczne gromadzenie wiedzy - jako wyraz przywiązania i miłości do samego siebie, krnąbrności i zuchwałości - jest hamującą przeszkodą $^{62}$. Tak scharakteryzowana etyczna postać rozumienia, $\mathrm{w}$ innym miejscu nazwanego przez Stuppericha „rozumieniem teologicznym" (theologische Verstehen), wynika wprawdzie z nieopracowanej przez Erazma zasady hermeneutycznej, ale jednak przekracza filologiczną jedynie egzegezę humanistów, skoro w „rozumieniu teologicznym" modlitwa i medytacja odkrywają decydującą funkcję $e^{63}$.

Po stronie dyskursywnej i noetycznej natomiast pozostaje jedynie, jak argumentuje Christine Christ-von Wedel, „grzeszna niewiedza człowieka powołanego na obraz boży". Wszelako jest to ten typ niewiedzy (Nichtwissen), który nie tylko nie ma sokratejskiego rodowodu ani nie jest wyrazem w najwyższym stopniu wystudiowanej kapitulacji rozumu, ale jest on czymś człowiekowi naturalnie przyrodzonym ${ }^{64}$. Takiej, trzeba to powiedzieć - jednostronnej wykładni sprzyjają analizowane przez Christ-von Wedel, Stuppericha i Kohlsa prace Erazma z okresu poprzedzającego jego dyskusję z Lutrem, a mianowicie Enchiridion, Paraclesis i Ratio vere theologiae. Tymczasem źródła i motywacje traktatów nieobjętych przez Kohlsa i Stuppericha analizą, jak De libero arbitrio oraz Hyperaspistes, z konieczności wymagały wydobycia i opisania również poznawczo konstruktywnej, jawnie noetycznej, dyskursywnej specyfiki rozumienia. Wszak przedmiotem sporu Erazma z Lutrem nie było Pismo jako takie albo możliwe, osobowo-egzystencjalne korzyści wynikające z jego medytacyjnej lektury, ale nade wszystko określona wykładnia

62 Zob. R. Stupperich, Erasmus von Rotterdam und seine Welt..., s. 130.

63 R. Stupperich, Die theologische Neuorientierung des Erasmus in der Ratio seu methodus 1516/18, w: Actes du Congres Erasme, Amsterdam 1971, s. 153.

64 Ch. Christ-von Wedel, Das Nichtwissen bei Erasmus von Rotterdam. Zum philosophischen und theologischen Erkennen in der geistigen Entwicklung eines christlichen Humanisten, Basel 1981, s. 52. 
(sensus) tekstu biblijnego, bez względu na to, czy była ona podana $\mathrm{w}$ trybie akumulacji argumentów czy asercji ${ }^{65}$.

Wprowadzony wówczas retoryczny sensus communis wskazuje nie tylko na powiązanie rozumienia $\mathrm{z}$ tym, co prawdopodobne, a więc perswazyjne, ale nade wszystko ujawnia, że interpretatio jako taka jest uzależniona od konkretnej sytuacji i jej zmieniających się uwarunkowań. W przeciwieństwie do wiążącego sądu (assertio), dopiero rozumienie jest adekwatnym wyrazem dla zmagań z tym, co przekracza zdolności poznawcze człowieka ${ }^{66}$. Istotną cechą rozumienia jest więc, zdaniem Erazma, dziejowość oraz wynikająca z owej dziejowości idiosynkratyczność sądów, nie zaś ich uniwersalnie i trwale wiążący charakter. Splatając w ten sposób interpretatio $\mathrm{z}$ generowanymi przez Biblię humanum captum excedentia Erazm wstępował na długą drogę tego namysłu hermeneutycznego, którego zwieńczeniem dokładnie cztery wieki później stanie się owa Heideggerowska eigentliche Hermeneutik, gdzie rozumienie zostało podniesione $\mathrm{z}$ wymiaru egzegetycznego do zasadniczej cechy ludzkiego bycia-w-świecie jako nieregulowanej metodycznie formy otwartości na świat, a więc do rozumienia dziejowości własnej egzystencjii ${ }^{67}$.

\section{Tradycja chrześcijańska jako autorytet}

Elementarny dla problemu rozumienia u Erazma podział na Scriptura i sensus okazał się jednak niewystarczający. Gdyby bowiem Erazm ograniczył się do tego rozróżnienia, jego stanowisko nie wykraczałoby poza ustalenia Orygenesa i opisane przez św. Augustyna rozróżnienie rzeczy i znaku. Wyjaśnienia w Hyperaspistes I, że nie o zawie-

65 Por. ibidem, s. 98-99.

66 Zob. LB, X, 1303C.

${ }_{67}$ Zob. M. Heidegger, Bycie i czas..., s. 210-218, 470-476. Zob. też niżej przypis 114. 
szanie sądów idzie, ale o unikanie pochopnych konkluzji-asercji ${ }^{68}$, dla chrystianizacji sceptycyzmu także byłyby niewystarczające, gdyby Erazm nie wprowadził jeszcze jednej, tym razem hierarchicznej relacji - między egzegetą a tradycją egzegetyczną.

Erazm podkreśla, że na skutek nie tylko naturalnych, ograniczonych zdolności poznawczych (imbecillitas), ale nade wszystko nabytych, jednostkowych uwarunkowań zmienia się samo rozumienie: „Czasem z powodu bezsilności ludzkiego intelektu Pismo nie jest pojmowane [...] otępienie władz umysłowych albo znużenie, czy też oddanie umysłu na użytek spraw ludzkich wielu osobom przeszkodziło lepiej pojąć naukę przekazaną w Piśmie" ${ }^{69}$. Co za tym idzie, „stanowisko potwierdzone publicznym autorytetem Kościoła - czytamy nieco wcześniej w Hyperaspistes I - wydaje się bardziej prawdopodobne od tego, które sformułowane zostało samodzielnie"70. Rozmyślne przedkładanie sądów, które łączą autorów o uznanym autorytecie, dodatkowo wspartych dawnością jako cechą pozytywną, nad pojedynczą wykładnię urasta u Erazma do podstawowej cechy rozumienia, które jest owocne poznawczo: „W rozumieniu Pisma Świętego wolę podążać za zdaniem autorów ortodoksyjnych i samego Kościoła niż za jedynie twoim zdaniem i nielicznych tobie zaprzysiężonych"71. Dzięki rozróżnieniu Pisma i jego wykładni, a w obrębie tej ostatniej przez zhierarchizowanie nadrzędnej tradycji i poznawczo podlegającego jej egzegety, Erazm nieśmiało zaczynał odsłaniać dziejową ontologię doświadczenia hermeneutycznego, w którym rozumienie staje się sposobem bycia człowieka. W przeciwieństwie do stanowiska Lutra, tradycja egzegetyczna i doktrynal-

68 Zob. LB, X, 1259B.

69 LB, X, 1306F, 1309E, 1310C. W innym miejscu Hyperaspistes I (LB, X, 1263D-E) Erazm podaje, za De doctrina christiana (II, 6, 7) św. Augustyna, analogiczną uwagę, kładąc tym razem nacisk na sam język Biblii, który może utrudniać rozumienie.

70 LB, X, 1297D.

71 LB, X, 1283E-F. Zob. też LB, X, 1303D, 1314E. 
na nie tylko nie udaremnia rozumienia, ale zasadniczo je generuje, a następnie umożliwia jego dalszy postęp.

Określający ową hierarchię dystans czasowy między tradycją a interpretatorem, nawet jeśli temu, co starsze, przypisywał większą wartość ${ }^{72}$, nie oznaczał bariery albo deprecjacji tego, co bieżące. Przeciwnie - dla teraźniejszości ów dystans był czymś istotnie pozytywnym. Pozwala on bowiem na trwające nawet wiele wieków weryfikacje osądów przekazanych w tradycji, a w rezultacie właśnie dopiero z perspektywy czasu pewne wypowiedzi mogą zostać albo zakwestionowane lub nawet odrzucone, albo uznane za adekwatne dla potrzeb danej sytuacji i dzięki temu obdarzone autorytetem. Czas jest nośnikiem atrofii i powstawania, stałości i zmiany, słowem - tego wszystkiego, co pozwala pojedynczemu interpretatorowi świadomie określić swoje miejsce $\mathrm{w}$ tradycji, a za pośrednictwem takiego miejsca krytycznie ocenić także swoje zdolności poznawcze. Dystans czasowy, obok powagi samego magisterium kościelnego, był dla Erazma głównym kryterium oceny danych osądów. Niezależnie od asertorycznego tonu wypowiedzi Lutra (ten był niezgodny z retoryczno-perswazyjnym, jedynie prawdopodobnym sensus communis), to właśnie brak owego dystansu czasowego dla jego wykładni Erazm przyjął za podstawowy argument za odrzuceniem stanowiska swojego adwersarza. „Przyznaję, że wykładnie różnią się między sobą. Zapytałem więc, którą z nich należy przyjąć: czy te przekazane przez dawnych autorów, potwierdzone tyloma wiekami, czy raczej twoje, które pojawiły się niedawno?"73 Nieco dalej, raz jeszcze i wedle tego samego klucza konfrontując stanowisko par excellence

72 Zob. P.G. Bietenholz, History and Biography in the Work of Erasmus of Rotterdam, Genève 1966, s. 23-46; J. Domański, Nova und vetera bei Erasmus von Rotterdam. Ein Beitrag zur Begriffs- und Bewertungsanalyse, w: Miscellanea Mediaevalia, Bd. 9: Antiqui und Moderni. Traditionsbewusstsein und Fortschrittsbewusstsein im späten Mittelalter, Berlin 1974, s. 519-527; J. den Boeft, „Illic aureum quoddam ire flumen". Erasmus' Enthusiasm for the Patres, w: Erasmus of Rotterdam. The Man and the Scholar, ed. J.S. Weiland, W.Th.M. Frijhoff, Leiden 1988, s. 172-174.

73 LB, X, 1312B. 
tradycyjne z pozbawioną takiego atrybutu postawą luteran, dodawał: „Po przeciwnej stronie stoją ci wyborni luminarze domu bożego, wśród których są umysły wybitne i biegłe w boskiej filozofii - zarówno Grecy, którzy w objaśnianiu Pisma Świętego zawsze posiadali największy autorytet, jak i autorzy łacińscy, rywalizujący z Grekami, [...] aż do dziś wśród całego ludu chrześcijańskiego pamięć o tych słynnych ludziach była nienaruszona - o tylu biskupach i papieżach, których zdanie zostało w ciągu wielu stuleci powszechnie przyjęte i potwierdzone, a wreszcie utrwalone przez publiczną naukę Kościoła. Dodaj do tego zgodny osąd wszystkich uniwersytetów, dodaj odnowioną ocenę teologów i Kościoła, wreszcie dodaj też zasadę, która wytrzymała tak długą próbę czasu"74. Dla Erazma wybór stanowiska $\mathrm{w}$ przedmiocie tego prawdziwie hermeneutycznego problemu był oczywisty.

W relacji między egzegetą a nadrzędną względem niego tradycją egzegetyczną zachodzi istotna współzależność. W czytelny, choć niestety nie dość usystematyzowany sposób Erazm przedstawia tradycję jako autorytet, czyli element asystujący, tj. wspierający rozumienie. Pojęcie auctoritas wskazuje w Hyperaspistes I na dziejowy sposób nie tylko bycia, ale nade wszystko rozumienia, które możliwe jest wyłącznie w obrębie tradycji. Skutkiem tego, co podkreśla Erazm w kontekście indywidualnego rozumienia Pisma, „porusza nas ich autorytet" 75 . Sięgając w innym miejscu po zmetaforyzowany język dla opisu relacji zachodzącej między tradycją egzegetyczną a jej beneficjentem-egzegetą niderlandzki uczony porównywał obdarzoną autorytetem tradycję m.in. do mleka matki, którym karmione jest dziecko: „czy mamy opuścić naszych ojców, których nauka, prawa i autorytet nas dotąd żywiły i prowadziły; wzgardzić matką, której mlekiem zostaliśmy wykarmieni; opuścić taką wspólnotę ludu chrześcijańskiego, do której od tylu lat przywykliśmy, by z największą szkodą dla życia i duszy przystąpić do twojego stowarzyszenia,

$\begin{array}{ll}74 & \text { LB, X, 1315D. } \\ 75 & \text { LB, X, 1316A. }\end{array}$ 
gdzie, wyłączywszy ledwie kilka, a i tak skłóconych ze sobą osób, dostrzegamy jedynie warowne asercje" ${ }^{\text {"76 }}$. W tej, chwilami nieco afektowanej wypowiedzi Erazma, powracają dwa elementy kluczowe dla jego myślenia o rozumieniu, takie jak wspólnota (sodalitas) oraz autorytet tradycji (patrum auctoritas). Pierwszy z tych elementów, ze względu na określające ową wspólnotę cechy - wewnętrzną zgodność myślenia i petryfikujący tę zgodność dystans czasowy - staje się adekwatnym ekwiwalentem sensus communis. Element drugi, czyli tradycja, dzięki pozytywnemu mandatowi otrzymanemu przez jej beneficjenta-egzegetę, porusza i wspiera rozumienie pojedynczego czytelnika Biblii. Należy jednak podkreślić, że owa hermeneutyczna sodalitas nie oznacza jedynie zbioru sądów, po które, gdy zachodzi taka potrzeba, sięga egzegeta. Wskazuje ona raczej na ontologiczną strukturę rozumienia ${ }^{77}$. Wbrew temu bowiem, co sądził Luter powołujący się w kontekście indywidualnych osądów na niezrozumiały dla Erazma charyzmat Ducha Świętego, tradycja jako potwierdzona dystansem czasowym i obdarzona autorytetem rada uczonych (eruditorum concilium) czyni w ogóle możliwym jednostkowe rozumienie Pisma Świętego ${ }^{78}$. Zarazem, poznawczo regulowana przez sensus communis i wypełniona ludzkimi, czyli skończenie-dziejowymi interpretationes, tradycja umożliwia, zdaniem Erazma, badanie i poszukiwanie tego, co w wykładni może być bardziej prawdopodobne (probabilius). Analogicznie bowiem do sensus communis, także rozumieniu Erazm przypisywał raczej atrybut prawdopodobieństwa niż pewności, choć nie był w tym konsekwentny.

Przez wzgląd na „rzetelne rozumowanie” (solida ratio), które wespół z dowodami skrypturystycznymi i tradycją jako autorytetem jest $\mathrm{u}$ Erazma jednym $\mathrm{z}$ trzech filarów rozumienia, poleganie na asystującym autorytecie tradycji nie zwalniało w hermeneutyce Erazma, czego Luter zdawał się nie dostrzegać, z każdorazowo krytycznej oceny

76 LB, X, 1315E-F.

77 Por. H.-G. Gadamer, Prawda i metoda..., s. 279.

78 Zob. LB, X, 1303D. 
tradycji. Przyjęty decyzjami soborów i potwierdzony praktyką egzegetyczną ortodoksyjny charakter wykładni wypełniających tradycję chrześcijańską nie miał bowiem wartości uniwersalnej i bezwzględnej. W rezultacie, interpretacje wypełniające tradycję nigdy nie tracą swojego skończenie-dziejowego charakteru. Co więcej, właśnie ze względu na swój dziejowy charakter wykładnie z konieczności wymagają skrupulatnej oceny, nie wyłączając, co zrozumiałe, nawet ich zakwestionowania: „niektóre [osądy] nie są ani ściśle słowem człowieka, ani Słowem bożym, lecz są dla Słowa bożego wykładniami, które czasem godzi się podawać w wątpliwość"79. Erazm otwarcie podkreślał, że sięganie po tradycję, a zatem autorów, którzy wymiernie i pozytywnie wpływają na nasze rozumienie, jest czynnością zdyscyplinowanego umysłu (constans animus). Mając bowiem na uwadze swoje ograniczenia i doceniając pozytywny wpływ dystansu czasowego na sam akt rozumienia, pojedynczy egzegeta jest zobligowany rozumować w hermeneutycznie staranny sposób. Oznacza to, że troszcząc się o poznawczą wartość własnych orzeczeń, egzegeta przedkłada autorytet Pisma (Scripturarum auctoritas), naukę Kościoła (Ecclesiae decretum), wreszcie osąd tylu autorów (opinio tot viri) nad pozbawiony dobrodziejstwa dystansu czasowego, a w rezultacie także autorytetu, jednostkowy osąd Lutra ${ }^{80}$. Ten ostatni nie miał, zdaniem Erazma, dla swoich asercji rozumnego uzasadnienia. Luter bowiem zbagatelizował własne bariery poznawcze, określone przez dziejowe uwarunkowanie egzystencji. W rezultacie miał on także zupełnie zignorować znaczenie tradycji, która, jeśli wsparta odpowiednimi procedurami heurystycznymi, umożliwia poznawczo konstruktywne rozumienie Pisma.

$\mathrm{Z}$ tego powodu już w Ratio verae theologiae, a więc tekście programowym dla myślenia teologicznego Erazma, wymagał on krytycznego stosunku do tradycji (cum iudicio delectuque), gdyż reprezentatywni dla niej autorzy „byli ludźmi, pewnych spraw nie

\footnotetext{
79 LB, X, 1290A.

80 Zob. LB, X, 1294A, 1298C, 1304E.
} 
znali, o innych wypowiadali się nierozsądnie, czasem bywali nie dość uważni" ${ }^{81}$. Siedem lat później w Hyperaspistes I tradycja została opatrzona dokładnie taką samą krytyczną klauzulą: „wprawdzie Pismu przypisuję największy autorytet, ale bynajmniej nie lekceważę tych wielkich autorów, którzy wspomagają nas w rozumieniu Pisma Świętego, nawet jeśli dobrze wiem, że będąc ludźmi czasem popełniają błędy" ". Ograniczone zaufanie do autorytetu tradycji towarzyszyło niderlandzkiemu uczonemu przez długie lata, czego potwierdzeniem jest jego ostatnia praca - Ecclesiastes. Ranga autorytetu została tam w najwyższym stopniu przypisana wyłącznie kanonowi biblijne$\mathrm{mu}$, a zarazem ów kanon został expressis verbis podniesiony do roli kryterium, wedle którego należy cum iudicio oceniać wszelkie jego wykładnie, czyli tradycję właśnie ${ }^{83}$. Tym bowiem zasadniczo różni się, zdaniem Erazma, autorytet Pisma w swojej kanonicznej postaci od autorytetu tradycji, że ten pierwszy jest bezczasowy, a więc ma normatywny i programowo niepodlegający zakwestionowaniu charakter, drugi zaś, ze względu na swoją dziejowość, nieustannie wymaga krytycznego rozpoznawania.

Erazm, a potwierdzają to również jego przytoczone wcześniej wypowiedzi, zdawał sobie sprawę, że podstawowym warunkiem krytycznie-konstruktywnego rozumienia, a więc bycia rozmyślnie włączonym w przekaz tradycji, jest uświadomienie sobie pośredniczącej roli języka. Będąc częścią tradycji, język jako sermo temporarius przekazuje tradycję w jednostkowy, idiosynkratyczny, z konieczności zmienny sposób. W obrębie tradycji, nawet w tych wypadkach, gdy amplituda trwałości i zmiany jest relatywnie niewielka, nie ma miejsca na uniwersalnie obowiązujące i logicznie zniewalające reguły rozumienia. „Myślenie rzeczywiście historyczne - napisze

81 Ratio seu methodus compendio perveniendi ad veram theologiam..., s. 295, 1. 22-23. Dalszą dokumentację źródłową podaje J.B. Payne, Toward the Hermeneutics of Erasmus..., s. 33.

82 LB, X, 1291E.

83 Zob. niżej przypis nr 92. 
w 1960 roku Hans-Georg Gadamer - musi uwzględniać także swoją dziejowość" 84 .

W tym względzie św. Augustyn, jako autor Retractationes, modelowo uosabiał dla Erazma tradycję samokrytyczną, bo świadomą swojej dziejowości i wynikających stąd ograniczeń: „autorytet jego myśli dlatego jest większy - ocenia Erazm - ponieważ w pewnych sprawach krytykował on sam siebie" 85 . By tradycja pozostała skutecznym narzędziem poznawczym, nieustannie wymaga ona potwierdzania cum iudicio delectuque. Stosunek Erazma do św. Augustyna dowodzi, że między narzędziami poznawczymi człowieka, przez niderlandzkiego uczonego rozmaicie nazywanymi (ratio, animus, ingenium) a autorytetem (auctoritas) nie zachodzi żadne przeciwieństwo. Sięganie bowiem po autorytet, a poświadcza to również praktyka egzegetyczna Erazma, to zawsze moment tzw. krytycznej wolności, rozumianej jako służąca gromadzeniu wiedzy zdolność do samokrytyki i świadomość własnych ograniczeń ${ }^{86}$, wolności, która - co należy z całą stanowczością podkreślić - nie ma nic wspólnego z bezkrytycznym posłuszeństwem wobec zdyskredytowanej przez Kanta komendy „nie myśleć!”. W akcie krytycznego rozpoznania to egzegeta obdarza pewnych autorów i pewne dzieła autorytetem, a więc mandatem, który pozwala autorom i dziełom asystować egzegecie w niekończącym się procesie poznawczym.

Egzegeta korzysta $z$ tradycji i ocenie tradycji oddaje swój wysiłek, ponieważ, mówiąc adekwatnym także dla myśli Erazma językiem dwudziestowiecznej hermeneutyki filozoficznej, „świadom swych granic uznaje lepszy wgląd innych" ${ }^{87}$. Tak typowy dla myśle-

84 H.-G. Gadamer, Prawda i metoda..., s. 284.

85 LB, X, 1314C.

86 Pojęciem „krytycznej wolności” (kritische Freiheit) posługuję się za Gadamerem. Zob. H.-G. Gadamer, Autorität und kritische Freiheit, w: idem, Über die Verborgenheit der Gesundheit. Aufsätze und Vorträge, Frankfurt am Main 1993, s. $156-157$.

87 H.-G. Gadamer, Prawda i metoda..., s. 268. Zob. też idem, Wahrheit in den Geisteswissenschaften, [w:] idem, Hermeneutik II. Wahrheit und Methode. Ergänzun- 
nia Erazma hermeneutyczny prymat autorytetu i tradycji nad indywidualnym sądem ${ }^{88}$, w dużym stopniu uzależniony był właśnie od samodzielnych decyzji rozumu, który różnicuje, zestawia, ocenia i w konsekwencji akceptuje lub odrzuca treści przekazane w tradycji. Zarazem tylko dzięki tradycji, a raczej tylko w jej obrębie, takie działanie rozumu jest możliwe. „Autorytet Kościoła - co słusznie skonstatował John Payne - w istotny sposób kształtował rozumienie Erazma, zarazem jego sceptyczno-humanistyczny umysł do pewnego stopnia klasyfikował orzeczenia takiego autorytetu" ${ }^{89}$. W rezultacie rozpoczęta w Diatrybie chrystianizacja sceptycyzmu jako pozytywnego i hermeneutycznie motywowanego stanowiska epistemologicznego została skierowana w Hyperaspistes I na nieco inny tor. Niedopuszczalne, zdaniem Lutra, składanie sądu doktrynalnego w cudze ręce Erazm usprawiedliwił w Hyperaspistes I w trojaki sposób. Po pierwsze, hierarchicznie rozróżnił egzegetę i tradycję egzegetyczną; po drugie, postawił przed egzegetą obligatoryjny wymóg heurystycznie-krytycznej oceny tradycji; po trzecie wreszcie, odsłonił dziejowy rodowód jednostkowych osądów egzegetycznych ${ }^{90}$.

Zdaniem Erazma stanowisko Lutra - przypisującego sobie całkowitą powagę rozumienia (certa auctoritas interpretandi) dzięki charyzmatowi Ducha Świętego - było potrójnie błędne ${ }^{91}$. Po pierwsze,

gen - Register, Tübingen 1993, s. 39-40. Na tę samą specyfikę funkcjonalną autorytetu i jego mocy, choć ujmowanego osobowo, zwracał uwagę W. Stróżewski, Mała fenomenologia autorytetu, w: idem, W kręgu wartości, Kraków 1992, s. 30.

${ }_{88} \mathrm{Na}$ temat nadrzędnego dla Erazma autorytetu Pisma zob. P. Walter, Theologie aus dem Geist der Rhetorik..., s. 130-140; M. Hoffmann, Erkenntnis und Verwirklichung der wahren Theologie..., s. 78-82; A. Rabil Jr., Erasmus and the New Testament..., s. 103-109. Na temat pojęcia autoritas Ecclesiae i jego ekwiwalentów zob. A. 1636, 3-5; A. 1637, 28-35, 59-67, 112-115; A. 1644, 15-17; A. 1678, 34-36; A. 1717, 52-56; A. 1729, 25-27; A. 1893, 56-70; A. 2175, 21-24. Skrót A.: Opus epistolarum Des. Erasmi Roterodami, ed. P.S. Allen, H.M. Allen, H.G. Garrod, t. 1-12, Oxford 1906-1958. Pierwsza liczba oznacza numer listu, druga wiersz.

${ }^{89}$ J.B. Payne, Erasmus. His Theology..., s. 154.

90 Zob. LB, X, 1262C.

91 LB, X, 1319B-C. Zob. też LB, X, 1319C. 
reformator $\mathrm{z}$ Wittenbergi zignorował pozytywny wpływ tradycji na akt rozumienia. Po drugie, przypisywana Lutrowi, owa certa auctoritas interpretandi, nie była $\mathrm{w}$ ogóle możliwa $\mathrm{z}$ powodu dziejowego charakteru ludzkiego języka (sermo temporarius) - w imię konstruktywnego rozumienia język, którym dysponuje egzegeta, wymaga bowiem przedkładania tradycji nad jednostkowy osąd. Wreszcie po trzecie, Lutrowa certa auctoritas interpretandi bezpodstawnie neutralizuje specyficznie ludzki, a więc skończenie-dziejowy charakter interpretatio. Przypisawszy sobie charyzmat Ducha Świętego, staje się ona typową dla proroków prophetia, czyli niedostępnym człowiekowi darem wykładania tajemnicy Pisma. Również tutaj, i znowu na prawach precedensu, dochodzi do głosu wspomniana za Ecclesiastes opozycja między bezczasowością woli bożej w Piśmie i dziejowością jej przedstawień w tradycji. Erazm bowiem nie tylko obdarzył tam Pismo hermeneutycznym atrybutem autorytetu, ale dla podkreślenia jego absolutnej nadrzędności opatrzył go nadto znamieniem nienaruszalności oraz niekwestionowalności (inuiolabilis auctoritas, irrefutabilis auctoritas). „Swoją wolę - czytamy w Ecclesiastes - Bóg przedstawił nam w pismach kanonicznych, którym przysługuje nienaruszalny autorytet. Cały zatem zbiór Pism obejmujących oba Testamenty czasem nazywa się prawem Boga. [...] Na tym bowiem polega [ich] niekwestionowalny autorytet. Wszystko inne należy przyjmować krytycznie i oceniać wedle boskiego wzorca"92. W świetle powyższej wypowiedzi, niejako podsumowującej hermeneutyczne doświadczenia Erazma, owa certa auctoritas interpretandi Lutra staje się niczym więcej, jak hermeneutycznym oksymoronem.

Wyrażona w taki sposób zasada nadrzędności Pisma nie oznaczała, co zrozumiałe, poznawczej dyskredytacji tradycji egzegetycznej. W rezultacie owa zasada w żaden sposób nie dezawuuje wcześniejszych wypowiedzi Erazma na temat autorytatywnej roli tradycji w rozumieniu. Co więcej, wykładnia opierająca się wyłącznie na

92 Ecclesiastes sive de ratione concionandi (Libri III-IV)..., s. 320, 1. 182-185, 187-189. 
tekście biblijnym, a pozbawiona pośrednictwa tradycji, jest w znacznie większym stopniu narażona na ryzyko manipulacji. Erazm pisze bowiem wprost, mając na myśli działanie jednostkowej i hermeneutycznie wyizolowanej subiektywności, o „naciąganiu Pisma do własnej wykładni”. Samo tylko przyjęcie Pisma jako normy (iudex) rozumienia nie wyklucza, jego zdaniem, sprzecznych interpretacji tego samego miejsca w tekście biblijnym ${ }^{93}$. W takich sytuacjach tradycja już nie tylko asystuje w procesie rozumienia, ale nade wszystko spełnia także rolę normatywną, skoro pozwala wybrać tę wykładnię Pisma, która jest bardziej prawdopodobna. Według Lutra taka komplementarna i programowo obligatoryjna relacja hermeneutyczna między Biblią a tradycją była niedopuszczalna. Poleganie bowiem na interpretatio jako skończenie-dziejowym, a więc jedynie prawdopodobnym rozumieniu Pisma, wymagającym ciągłych poprawek i potwierdzeń, było równoznaczne ze stanowiskiem sceptycznym, zupełnie obcym chrześcijaństwu ${ }^{94}$. Jednakowoż chrześcijański sceptycyzm, jako rozumnie zdyscyplinowany namysł nad znaczeniem Pisma, rozluźnia dyskurs wyznaniowy na drodze wzajemnych, trwających nawet wiele stuleci konsultacji egzegetycznych. Praktycznym zastosowaniem tej strategii hermeneutycznej i epistemologicznej była już sama Diatryba Erazma, której leksykalnie wieloznaczny gre-

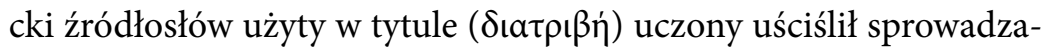
jąc go do łacińskiej, dużo bardziej przejrzystej collatio. Ta oznaczała 'gromadzenie', ewentualnie też 'zestawienie' i 'porównanie' wiedzy zawartej w tradycji. Możliwa dzięki autorytetowi tradycji indywidualna interpretatio była, zdaniem Erazma, niczym więcej jak pośrednim ogniwem w długiej tradycji egzegetycznej. Innymi słowy, interpretatio to raczej pośrednik tradycji niż rezultat takiego badania, które w nieuzasadniony sposób ignoruje swoją dziejowość.

Bez uciekania się do pojęciowej manipulacji Erazm mógł zatem nazwać sceptykami nie tylko ojców Kościoła, ale nawet sam Kościół,

93 LB, X, 1298F.

94 Zob. De servo arbitrio..., s. 603, 1. 28-29. 
który w najtrudniejszych kwestiach przyjmował, jego zdaniem, postawę sceptyka ${ }^{95}$. W odpowiedzi na batalię Lutra o sens absolutny Erazm proponował „koncyliacyjne” rozumienie tekstu, by sięgnąć po adekwatne tu określenie Odo Marquarda ${ }^{96}$. Koncyliacyjność rozumienia Pisma polegała u Erazma na wyeksponowaniu językowego aspektu tekstu biblijnego, a więc jego hermeneutycznej wielopostaciowości, która każdorazowo przeciwdziała syngularyzacji Objawienia do postaci jednego sensu absolutnego. Kto nie zna języków klasycznych albo nie docenia, jak Luter wedle nie dość precyzyjnej oceny Erazma, ich destabilizującego wpływu na lekturę, ten nie jest zdolny przyznać, że tekst może znaczyć coś innego, niż się sądzi.

Gdy Erazm nie krył rozczarowania w Hyperaspistes I, a następnie $\mathrm{w}$ Purgatio adversus epistolam non sobriam Lutheri, $\mathrm{z}$ powodu tonu wypowiedzi swojego adwersarza, to zwracał uwagę, że Lutrowi brak było dialektycznie rozumianej modesti $a^{97}$. Erazmowi nie chodziło bowiem o skądinąd temperamentne usposobienie Lutra, ale o specyficznie rozumiany termin techniczny ze swojego teologicznego dykcjonariusza. Modestia, o czym mowa w Ratio verae theologiae, wespół z funkcjonalnie dla niej równoważnym umiarem (sobrietas) jako pojęciem już na poły dialektycznym, została uznana za podstawę poznawczo owocnej dyskusji, którą Erazm określił terminem collatio, czyli 'akumulacją argumentów ${ }^{98}$. Służąc takiemu właśnie

95 LB, X, 1262D. Zob. też. LB, X, 1258D, 1262D.

96 O. Marquard, Pytanie o pytanie, na które odpowiedzia jest hermeneutyka, w: idem, Rozstanie z filozofia pierwszych zasad. Studia filozoficzne, przeł. K. Krzemieniowa, Warszawa 1994, s. 138-139.

97 Zob. LB, X, 1309B; Purgatio adversus epistolam non sobriam Martini Lutheri, Hg. von C. Augustijn, w: Opera omnia Desiderii Erasmi Roterdami, ord. 9, t. 1, Amsterdam 1982, s. 474, 1. 863-865.

98 Zob. Ratio seu methodus compendio perveniendi ad veram theologiam..., s. 180, 1. 30-31. Zob. również ibidem, s. 181, 1. 11-14. Na temat owych inkluzyjno-akumulacyjnych funkcji dialektyki wczesnonowożytnej i spełniających takie funkcje sylwicznych zbiorów loci communes theologici zob. U.B. Leu, Aneignung und Speicherung enzyklopädischen Wissens. Die Loci-Methode von Erasmus, w: Erasmus in Zürich. Eine verschwiegene Autorität, Hg. von Ch. Christ-von Wedel, U.B. Leu, 
gromadzeniu argumentów modestia oznacza zatem tryb inkluzyjnego dowodzenia skrypturystycznego, które na skutek ograniczeń poznawczych egzegety opiera się nie tylko na Piśmie, ale także na asystującej, a w szczególnych wypadkach również normatywnej tradycji egzegetycznej. Pokierowana przez taką, dialektyczną modestia „koncyliacyjność” rozumienia Biblii rozluźniała dyskurs wyznaniowy. Modestia bowiem obdarzała mocą decyzyjną także tradycję składającą się z „tych postanowień Kościoła powszechnego, które zostały wydane przez sobory powszechne i potwierdzone zgodą społeczności chrześcijańskiej"99. Tak samo jak specyficznie pojmowana zasada nadrzędności Pisma uzasadnia asercje Lutra, tak tradycja egzegetyczna, jako szczególna postać autorytetu, warunkuje metodyczny sceptycyzm Erazma.

Ufam, że z powyższej prezentacji wynika już, iż Erazm przypisywał tradycji zdolność odsłaniania prawdy innej niż ta, która jest weryfikowana albo przez racjonalne, po Kantowsku czyste reguły falsyfikacji, albo przez uniwersalne procedury egzegezy, typowe dla humanistycznej krytyki historycznej oraz dla hermeneutyki Lutra. Ani bowiem uniwersalna metoda, z której Erazm korzystał, ani tym bardziej niezrozumiałe dlań przekonanie Lutra o zewnętrznej jasności Pisma, nie oddawało sprawiedliwości niepowtarzalnym uwarunkowaniom jednostkowego człowieka, który sięga po Biblię celem zrozumienia logocentrycznej rzeczywistości, w jakiej żyje. Dopiero dzięki umieszczeniu Pisma w obrębie tradycji adekwatnie odpowiadało ono idiosynkratycznym, nie zaś tylko uniwersalnym motywacjom człowieka. Rozumienie dostarcza zatem wiedzy, która nie jest nieuwarunkowana i po Kantowsku czysta, której przysługuje atrybut raczej prawdopodobieństwa niż pewności. Dzieląc jednak sprawied-

Zürich 2007, s. 327-342; G.B. Winkler, Erasmus von Rotterdam und die Einleitungsschriften zum Neuen Testament..., s. 219-236; G. Bader, Assertio..., s. 43-58; M. Hoffmann, Rhetoric and Theology..., s. 151-156, 178-181; P. Walter, Theologie aus dem Geist der Rhetorik..., s. 189-194; G. Frank, Topik als Methode der Dogmatik. Antike - Mittelalter - Frühe Neuzeit, Berlin 2016, s. 159-210.

99 LB, X, 1262A-B. 
liwie straty i korzyści, należy podkreślić, że tylko za pośrednictwem rozumienia człowiek dysponuje wiedzą, która dzięki programowo antyfundamentalistycznemu charakterowi odpowiada jego świadomości historycznej; wiedzą, która wymyka się rygorowi zunifikowanego porządku dyskursywnego. Pomimo tych wszystkich antyfundamentalistycznych cech wiedza dostarczana przez rozumienie nie przestaje mieć rozumnego charakteru, ponieważ wymiernie wspierający ją autorytet tradycji wymagał krytycznych, cum iudicio delectuque, a więc właśnie rozumnie zdyscyplinowanych i heurystycznych decyzji. Co za tym idzie, epistemologia hermeneutyczna Erazma dostarcza wiedzy par excellence praktycznej. Jest ona o tyle

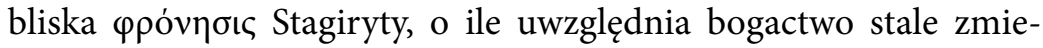
niających się okoliczności i jako taka stanowi podstawę dla tego, co Erazm, za retoryką rzymską, nazywał sensus communis.

Obecna w pismach Erazma jedynie w zalążkowej postaci, zrekonstruowana tu ontologia doświadczenia hermeneutycznego umieszczała akt rozumienia w samym środku tradycji, czym odsłaniała jego dziejowy charakter. W strukturze takiego doświadczenia w szczególny sposób została powiązana materia rozumienia (jako element tradycji) z aktem rozumienia i bazującym na nim osądem. Respektując bowiem kluczową dla Erazma poznawczą i hermeneutyczną nadrzędność tradycji nad pojedynczym osądem, taki związek polegał nie na uprzedmiotawiającym dystansowaniu się aktu rozumienia od tego, co rozumiane, ale na receptywnym i zarazem krytycznym uczestnictwie w samej materii rozumienia. Schematyczna struktura odgraniczająca podmiot poznający od przedmiotu poznawanego była raczej obca wrażliwości hermeneutycznej Erazma. Pod względem receptywnym rozumienie tradycji jest bowiem możliwe tylko w obrębie tradycji. W dalszej zaś, krytycznej perspektywie, rozumienie na prawach uczestnictwa w tradycji winno ją oceniać i modyfikować z samego jej środka. Jest ono nie tylko integralną częścią tradycji, ale również jej pośrednikiem. Rozumienie jest więc możliwe tylko dzięki tradycji, pośrednicząc zaś jako jej ogniwo zajmuje się tradycją i wreszcie samo tę tradycję uzupełnia. „Interpretacja - mówiąc adekwatnym tu językiem Paula Ricoeura - jest więc aktem 
wspólnoty interpretującej, refleksyjnym wycinkiem tej wspólnoty w tej mierze, w jakiej sama jest wspólnotą tradycji" ${ }^{100}$. Innymi słowy, tradycja nie spowalnia ani tym bardziej nie unicestwia rozumienia, ale je inicjuje i umożliwia jego poznawczy postęp.

Dziejowo uwarunkowana, stale uczestnicząca we wspólnocie tradycji i na niej ufundowana, bo uzależniona od asystujących autorytetów, Erazmowa interpretatio sytuuje się na przeciwnym biegunie względem hermeneutyki Lutra. W tej ostatniej bowiem interpretari ustępowało miejsca assequi, czyli wymogowi, by „doskonale znać i widzieć”, jak czytamy w De servo arbitrio ${ }^{101}$. Takie stanowisko było więc równoznaczne $\mathrm{z}$ posiadaniem dziejowo indyferentnego charyzmatu Ducha Świętego i neutralizowaniu czy wręcz ignorowaniu wielopostaciowości autorytetu ${ }^{102}$. Zdaniem Erazma natomiast była to postawa tyleż jałowa poznawczo, co dla samego chrześcijaństwa szkodliwa. Asercje bowiem, jak niderlandzki uczony wyjaśniał $\mathrm{w}$ jednym $\mathrm{z}$ listów, generują raczej podziały wyznaniowe, niż służą konstruktywnemu rozpoznaniu newralgicznych problemów ${ }^{103}$. Poszukując jednego i trwałego sensu Pisma pośród rozmaitych sensów przekazanych przez tradycję Luter wywoływał „wojnę domową o sens absolutny"104, którą Erazm starał się rozumnie załagodzić, ponieważ zupełnie nie rozwiązywała ona problemu hermeneutycznego. Trwająca wiele wieków empiryczna obserwacja przekonuje bowiem, że każdy z nas, co podkreślał w Hyperaspistes I, wciąż dysponuje swoim idiosynkratycznym rozumieniem, którego dziejowej

100 P. Ricoeur, Egzegeza i hermeneutyka, przeł. S. Cichowicz, w: idem, Egzystencja $i$ hermeneutyka. Rozprawy o metodzie, wybór, oprac. i wprowadzenie S. Cichowicz, Warszawa 1985, s. 333. Zob. też H.-G. Gadamer, Prawda i metoda..., s. $270,272$.

101 De servo arbitrio..., s. 605, 1. 10-11.

102 Zob. ibidem, s. 609, 1. 11-12.

103 Zob. A. 2175, 5-11.

104 Określenie „wojny domowej o sens absolutny” zaczerpnąłem od Marquarda. Zob. O. Marquard, Pytanie o pytanie, na które odpowiedzia jest hermeneutyka..., s. $134-137$. 
specyfiki nie znosi bezpodstawne powoływanie się na obcy takiej interpretatio charyzmat Ducha Świętego ${ }^{105}$.

\section{Oceny i perspektywy}

Przeszło cztery dekady temu, we wstępie do swojej wciąż nieprześcignionej monografii Erazm i filozofia, Juliusz Domański diagnozował: „Erazm z Rotterdamu nie należy zapewne do osobistości, które by się z dziejami filozofii kojarzyły spontanicznie [...] Również dla historyków filozofii jakichkolwiek orientacji nie zdaje się być postacią pierwszoplanową"106. Dla historii hermeneutyki filozoficznej natomiast niderlandzki uczony jest w zasadzie postacią nieznaną ${ }^{107}$ (w przeciwieństwie do dziejów filologii oraz egzegezy biblijnej). W dziejach bowiem tego, co Heidegger nazwał eigentliche Hermeneutik, a więc hermeneutyki, która wykracza poza swój metodycznie-egzegetyczny wymiar ku rozumieniu będącemu podstawowym rysem egzystencji, myśl Erazma nie figuruje nawet na dalekich jej rubieżach.

Rozpoczęta już w 1936 roku krytycznymi ocenami Pfeiffera, a trzy dekady później wznowiona przez Kohlsa, nieśmiała i raczej przyczynkowa dyskusja na temat hermeneutycznego wymiaru my-

105 Zob. LB, X, 1299B-C.

106 J. Domański, Erazm i filozofia..., s. 15. Pierwsze wydanie ukazało się w 1973 roku.

107 Por. P. Walter, Theologie aus dem Geist der Rhetorik..., s. 259-261. Pozytywna ocena, jaką Walter wystawia aktualności hermeneutyki Erazma, nie powinna być jednak myląca. Pisząc o niej, Walter ma bowiem na myśli egzegezę biblijną, nie zaś opisany tu problem rozumienia i ontologii doświadczenia hermeneutycznego. Do analogicznych wniosków dochodzi też Mary Barnett. Autorka wskazuje wprawdzie pewną analogię z Gadamerowską ontologią doświadczenia hermeneutycznego, ale kontekst takiego porównania, skądinąd bardzo swobodnego, w całości zawiera się w filologii biblijnej Erazma, a ściślej w jego tekstologicznych zmaganiach z greckim tekstem Nowego Testamentu. Zob. M.J. Barnett, Erasmus and the Hermeneutics of Linguistic Praxis, „Renaissance Quarterly” 49 (1996), No. 3, s. 567-568. 
śli Erazma ostatecznie ugrzęzła po kilkudziesięciu latach na aporetycznej mieliźnie. Kompromisowe, ale chyba też kapitulujące rozwiązanie, które dobrze jednak oddaje specyfikę większości, jeśli nie wszystkich dotychczasowych prac na temat hermeneutyki Erazma, zaproponował przed laty trzydziestoma Friedhelm Krüger. W obliczu bowiem niekończącej się, bezowocnej i bezużytecznej dyskusji na temat pojęcia hermeneutyki u niderlandzkiego uczonego Krüger zasugerował, by wciąż pozbawioną rozstrzygającej konkluzji analizę tego wieloznacznego i problematycznego pojęcia zastąpić systematycznym badaniem przedmiotu Erazmowej teologii ${ }^{108}$.

Dla dyskutowanej tu problematyki sugestia Krügera oznacza zasadniczo dwie rzeczy. Po pierwsze, rozumienie w refleksji Erazma traci swoje autonomiczne miejsce, skoro jedynym właściwym dla niego umiejscowieniem staje się teologia, w ramach której rozumienie spełnia wprawdzie ważną, ale już niesamodzielną rolę. Po drugie i zarazem najważniejsze, na teologicznym gruncie, a nawet w obrębie akcentowanej przez Kohlsa Schrifttheologie, kwestia rozumienia nigdy nie wydostanie się poza rozmaicie modyfikowane, ale zawsze ograniczające ją egzegetyczne jedynie motywacje. W konsekwencji, Erazmowa interpretatio na zawsze już pozostanie tym, czym w gruncie rzeczy była dotychczas - skamieliną i drobnicą po akademicku wydobywaną z wyjątkowo odległej dla nas prehistorii hermeneutyki. Jednakowoż, jeśli wcześniej podejmowano sporadyczne próby odnalezienia w hermeneutyce Erazma tych elementów, które mogą być precedensowe dla wybranych, współczesnych nurtów hermeneutycznych (przede wszystkim dla hermeneutyki teologicznej oraz dla metody historyczno-krytycznej teologii liberalnej), to niestety odbywało się to w sposób wysoce powierzchowny. W konsekwencji

108 F. Krüger, Humanistische Evangelienauslegung..., s. 3-4. Streszczenie owej dyskusji podaje P. Walter, Theologie aus dem Geist der Rhetorik..., s. 1-6. 
wnioski takich rozpoznań okazały się wyjątkowo dyskusyjne, by nie powiedzieć wręcz - bezwartościowe ${ }^{109}$.

W omawianym tutaj kontekście dosyć znamienna, aczkolwiek odosobniona, pozostaje diagnoza Dietricha Hartha. Na podstawie filologicznych i pedagogicznych osiągnięć Erazma Harth wprawdzie dostrzegł krytyczny potencjał jego hermeneutyki, ale wciąż, i raczej po stronie strat niż zysków, zwracał uwagę na niezdolność Erazma do pełnego wyzwolenia się, w imię lepszego rozumienia, od przed-sądów (Vorurteile) dogmatycznej tradycji katolicyzmu ${ }^{110}$. Taka ocena ma swoje uzasadnienie na poziomie koncepcyjnym. Harth skłania się tu bowiem ku pojmowaniu hermeneutyki jako obiektywizującej metody rozumienia, co oznacza filologiczne wykładanie tekstów i ich praktyczne zastosowanie (Auslegung und Anwendung). Wszelako w takiej perspektywie jego diagnoza wciąż przysłania elementy dla Erazmowej hermeneutyki kluczowe. Mianowicie uniwersalny horyzont rozumienia, który jest regulowany z jednej strony przez swój nieodmiennie, niezbywalnie i bez względu na sytuację idiosynkratyczny i poznawczo konstruktywny nerw; z drugiej zaś przez wielopostaciową tradycję, która nie jest już zbiorem przesądów, ale stanowi pozytywnie asystujący i krytycznie obrany autorytet.

Najnowsze prace poświęcone hermeneutyce wczesnonowożytnej wprawdzie realizują postulat Krügera w czytelny i rzeczywiście konstruktywny sposób, ale odbywa się to kosztem zawężenia samego pojęcia hermeneutyki. Jest ona bowiem ujmowana albo jako normatywna teoria dla uprawiania teologii, filozofii oraz prawa, albo

109 Powyższa uwaga odnosi się do książki Johna Williama Aldridge’a The Hermeneutic of Erasmus, Richmond 1966.

110 D. Harth, Philologie und praktische Philosophie. Untersuchungen zum Sprachund Traditionsverständnis des Erasmus von Rotterdam, München 1970, s. 165-166. Analogicznie negatywną ocenę hermeneutyce Erazma, wszelako tylko na podstawie jego Enchiridion militis christiani, wystawił Gerhard Ebeling. Pomimo bowiem krytycznych deklaracji pod adresem egzegezy scholastycznej Erazm nie przestawał, zdaniem Ebelinga, polegać na patrystycznej i średniowiecznej alegorezie. Zob. G. Ebeling, Evangelische Evangelienauslegung..., s. 139. 
jako metodyczna podstawa praktyki wykładania tekstów biblijnych, klasycznych oraz prawniczych ${ }^{111}$. Analogiczną, jeśli nie tożsamą tendencję można zaobserwować także w opracowaniach hermeneutyki Erazma, które opublikowano w ciągu ostatnich dwóch dekad. Owe syntezy teologii Erazmowej podejmuja problem hermeneutyczny albo w kontekście retorycznym (jak w wypadku monografii Petera Waltera i Manfreda Hoffmanna), albo w nieco szerszym wymiarze filologicznym (gramatyka, krytyka tekstu, teoria przekładu), czego potwierdzeniem jest ostatni, monograficzny numer periodyku „The Bible Translator" poświęcony Nowemu Testamentowi Erazma ${ }^{112}$. Przezwyciężywszy w konstruktywny sposób wątpliwości Pfeiffera i Kohlsa, dzisiejsze studia nad hermeneutyką Erazma wciąż jednak nie wychodzą poza ramy tradycyjnego dyskursu badawczego, $z$ jednym wszelako zastrzeżeniem. Hermeneutyka mianowicie, w imię jasności i spójności samego wywodu poświęconego tak niejednoznacznemu i problematycznemu pojęciu, aktualnie jest dyskutowana w nadrzędnym dla niej teologiczno-filologicznym kontekście, gdzie spełnia jedynie propedeutyczną funkcję. Uniwersalność i samodzielność problemu hermeneutycznego u Erazma nie zostały do tej pory, o ile mi wiadomo, pozytywnie zidentyfikowane. Niniejsza praca jest natomiast taką próbą sproblematyzowania hermeneutyki

111 Zob. G. Frank, S. Meier-Oeser, Einleitung: Hermeneutik - Methodenlehre - Exegese. Zur Theorie der Interpretation in der Frühen Neuzeit, w: Hermeneutik, Methodenlehre, Exegese. Zur Theorie der Interpretation in der Frühen Neuzeit, Hg. von G. Frank, S. Meier-Oeser, Stuttgart 2011, s. 9; Hermeneutik. Die Geschichte der abendländischen Textauslegung bis zur Gegenwart, Hg. von M. Böhl, W. Reinhard, P. Walter, Wien 2013, s. 75-77, 179-203. Nawet jeśli podkreśla się krytyczno-historyczną doniosłość wczesnonowożytnej hermeneutyki biblijnej, to wciąż taka ocena jest ulokowana w obrębie określonych procedur interpretacyjnych (zob. Hermeneutik. Die Geschichte der abendländischen Textauslegung..., s. 179).

112 Zob. P. Walter, Theologie aus dem Geist der Rhetorik. Zur Schriftauslegung des Erasmus von Rotterdam, Mainz 1991; M. Hoffmann, Rhetoric and Theology. The Hermeneutics of Erasmus, Toronto 1994; “The Bible Translator" 67 (April 2016), Issue 1: Fidelius, apertius, significantius. The New Testament Translated and Edited by Erasmus of Rotterdam, 1516, ed. M.H. de Lang. 
niderlandzkiego uczonego, która nie mieści się w dotychczas obowiązujących badawczo ramach egzegezy i filologii humanistycznej.

Ufam zatem, że zrekonstruowany tutaj, obecny u Erazma wstępny i niedoskonały zarys ontologii doświadczenia hermeneutycznego, $\mathrm{z}$ rozumieniem jako właściwym człowiekowi sposobem bycia, pozwoli dostrzec w nim myśliciela o wrażliwości hermeneutycznej jeśli nie tej samej miary i znaczenia co Luter (na to jest jeszcze zdecydowanie za wcześnie), to chociaż autora, którego refleksja hermeneutyczna nie ogranicza się wyłącznie do „teologii Pisma” albo do metodycznego i filologicznego myślenia o prawidłach egzegezy. Jeśli przyznać rację lapidarnej ocenie Stuppericha - co wcale nie jest tak oczywiste - że hermeneutyka Erazma „nadal pozostaje fazą przejściową $\mathrm{w}$ porównaniu $\mathrm{z}$ późniejszymi hermeneutykami reformacji”, to jednak - co już znacznie bardziej zasadne - „właśnie on przecież przełamał wiele barier w stosunku do średniowiecza i wskazał nowe drogi"113. Zainicjowanej tutaj rewaluacji wkładu Erazma $\mathrm{w}$ historię hermeneutyki z pewnością nie ułatwiają jego nieuporządkowane, bo rozsiane w wielu miejscach wypowiedzi. Wprawdzie całościowo tworzą one raczej spójny obraz, ale wymagający znacznego wysiłku rekonstrukcyjnego, który, co oczywiste, wciąż pozostaje obarczony swoją dziejowością. Erazm nigdy nie zajmował się rozumieniem jako problemem samodzielnym, nie poświęcił mu żadnej osobnej pracy. Skądinąd jednak nie zrobił tego także, doceniony przez hermeneutykę filozoficzną ostatniego stulecia, Luter.

To, co w tytule niniejszego, wstępnego opracowania nazwałem „epistemologią hermeneutyczną,, jest arbitralnym, co nie znaczy jednak samowolnym i autorytarnym, ale raczej krytycznie rozumnym wariantem pojęcia „sceptycyzmu chrześcijańskiego” (wszak gr.

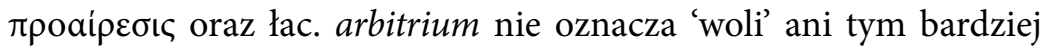
'chcenia', ale właśnie 'rozważny wybór', czyli 'namysł' i 'możliwość wydawania osądu', który ocenia i różnicuje możliwości wyboru).

113 R. Stupperich, Die theologische Neuorientierung des Erasmus..., s. 153 [podkreślenie moje - J.K.]. 
Jeśli zatem zrezygnowałem $\mathrm{z}$ drugiego $\mathrm{z}$ tych określeń, posiadającego przecież bogatą dokumentację źródłową i dobrze od kilku dekad zadomowionego w literaturze poświęconej Erazmowi, a wybrałem pierwsze, co trzeba otwarcie przyznać - anachroniczne określenie „epistemologii hermeneutycznej”, to kierowałem się tu jedną zasadniczo troską. Chodziło mianowicie o dowartościowanie hermeneutycznego problemu rozumienia, które w badaniach nad sceptycyzmem Erazma dotychczas w ogóle nie dochodziło do głosu. Rozumienie, już w Diatrybie umieszczone w perspektywie noetycznej, wciąż pozostawało dla Erazma określonym sposobem poznawania tekstu biblijnego, a więc metodycznie regulowanym postępowaniem egzegetycznym. Ze względu jednak na sproblematyzowanie dziejowego charakteru rozumienia, którego nie neutralizowała już absolutnie żadna metoda lektury, interpretatio stawała się czymś więcej niż tylko prowadzącym do konkretnego osądu narzędziem egzegetycznym.

W perspektywie standardów myślenia niemieckiej hermeneutyki filozoficznej ostatniego stulecia, która rozumienie potraktowała najpierw jako podstawowy sposób bycia (nie zaś poznawania) człowieka jako bytu przytomnego (Dasein), a następnie zasadę kompleksowo już opisanej ontologii doświadczenia hermeneutycznego (z pojęciem tradycji jako warunkiem koniecznym rozumienia) ${ }^{114}$, teoriopoznawcze stanowisko Erazma wciąż podlegało, aczkolwiek nie całkowicie, rygorowi metody. Wprawdzie Erazmowa interpreta-

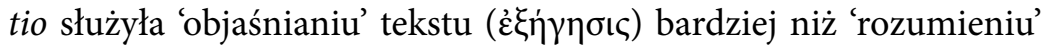
egzystencji, ale dziejowej specyfice tej ostatniej oddawała już nieco sprawiedliwości. Najczęstszy kontekst dla problemu rozumienia stanowiła u Erazma egzegeza nowotestamentowa, był on przecież jej filologicznym wirtuozem. W rezultacie, w niewielkim stopniu został odkryty przez Erazma uniwersalny wymiar i znaczenie autorytetu. Najczęściej autorytet odnosił się bowiem do poznania albo trady-

114 Zob. M. Heidegger, Bycie i czas..., s. 470-471; H.-G. Gadamer, Prawda i metoda..., s. 25. 
cji chrześcijańskiej, ściślej zaś nowotestamentowej, albo wybranych elementów tradycji klasycznej, które temuż chrześcijaństwu miały propedeutycznie służyć.

Obok autorytetu tradycji rozumieniu towarzyszy także metoda lektury, która prowadzi je ku określonemu osądowi (opinio). Należy jednak raz jeszcze zwrócić uwagę, że właściwym kryterium oceny takiego osądu nie jest prawda regulowana ścisłymi kryteriami falsyfikacji sądów, lecz typowe dla sensus communis prawdopodobieństwo, które podlegając retorycznej perswazji, nie ignoruje dziejowego uwarunkowania samego aktu rozumienia. Innymi słowy, wprawdzie Erazm łączył interpretatio z wykluczonym przez Heideggera poza ontologiczny sens rozumienia „sposobem poznawania” (Art von Erkennen $)^{115}$, ale ów egzegetyczny sposób nie gwarantował, zdaniem Erazma, bezwzględnej pewności. Każdy autorytet nieustannie wymaga bowiem skrupulatnego potwierdzania. Gdyby zamknąć wrażliwość hermeneutyczną Erazma w granicach egzegezy, to wypada wówczas podkreślić, oddając uczonemu historyczną sprawiedliwość, że nie ulegał on temu, co Ricoeur nazwał „fanatyzmem metodologicznym". Wyrazem takiego fanatyzmu jest przekonanie, że zdyscyplinowana metoda objaśniania tekstów (egzegeza) dysponuje wyłącznym prawem do ich rozumienia ${ }^{116}$.

W hermeneutyce Erazma prymat metody jest wysoce osobliwy. Metoda określa wprawdzie procedury myślenia i wobec ludzkich ograniczeń nadaje myśleniu względnie konstruktywny poznawczo charakter, ale zarazem odsłania, w imię dziejowej egzystencji człowieka i dostępnego mu jedynie sermo temporarius, granice jego zdolności poznawczych. Świadomie i rozmyślnie stosowane przez niderlandzkiego uczonego zasady nadawały kolejnym wykładniom status jedynie możliwy i prawdopodobny. Nigdy zaś nie gwarantowały odmówionej Lutrowi i niesłusznie uwolnionej od dziejowego

115 M. Heidegger, Sein und Zeit, Frankfurt am Main 1977, s. 444.

116 Zob. P. Ricoeur, Egzegeza i hermeneutyka..., s. 327. 
uwarunkowania certa auctoritas interpretandi117. Niezależnie od znacznego wysiłku teoriopoznawczego Erazm nigdy nie przypisywał sobie wyłącznych praw do formułowanych trwale wiążących osądów egzegetycznych. Prawda ani nie była jego własnością, ani on sam nie chciał jej posiadać na wyłączność. Opisując swoje stanowisko hermeneutyczne porównywał rolę wykonanej przez siebie pracy m.in.

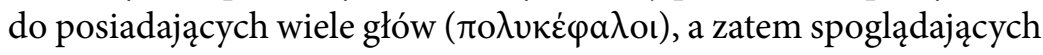
w różnych kierunkach posążków Merkurego-Hermesa, mitycznego patrona hermeneutyki. Na rozdrożu wprawdzie wskazują one drogę, ale $\mathrm{w}$ istocie nigdy nie docierają do celu ${ }^{118}$. Nawet jeśli inne ścieżki przywiodły myślenie Erazma do tej fundamentalnej dla hermeneutyki filozoficznej metafory, to trudno o bardziej Heideggerowską intuicję - Wege, nicht Werke.

Z tego również powodu uznałem hermeneutykę filozoficzną Heideggera, Bultmanna i Gadamera za dużo bardziej adekwatną perspektywę dla opisu i synchronicznej oceny stanowiska Erazma niż przykładowo prace Dilthey’a oraz Emilio Bettiego. Akcentowane bowiem przez obu z nich metodyczne, obiektywno-naukowe aspiracje rozumienia przysłaniały jego dziejowy charakter. Wprawdzie typowy dla stanowiska hermeneutycznego Erazma prymat tradycji nad indywidualnym sądem zbliża go do opisanej przez Dilthey’a poznawczej hierarchii między ogólnym, wygenerowanym przez indukcję doświadczeniem życia a stanowiącym podstawę indukcji indywidualnym doświadczeniem ${ }^{119}$; wprawdzie poznawcze motywacje Erazmowej hermeneutyki są bliskie epistemologicznemu pojęciu rozumienia, którego naukowym i obiektywnym ambicjom miały

117 Innymi słowy, Erazm nie popełniał błędu, na który zwracał uwagę Gadamer w kontekście rehabilitacji tzw. przed-sądów, czy szerzej - ontologicznej roli tradycji; zob. H.-G. Gadamer, Prawda i metoda..., s. 284.

118 Zob. Ratio seu methodus compendio perveniendi ad veram theologiam..., s. $178,1.1-3$.

119 Zob. W. Dilthey, Der Aufbau der geschichtlichen Welt..., s. 133. Takich analogii można odnaleźć znacznie więcej. Każdorazowo jednak umieszczają one rozumienie w ramach określonych procedur. 
służyć, zdaniem Bettiego, cztery procedury interpretacji, czyli kanony pracy $\mathrm{z}$ tekstem ${ }^{120}$, ale dopiero myśl Bultmanna, a nade wszystko Heideggera i Gadamera pozwala odsłonić w Hyperaspistes I treści precedensowe dla filozoficznie pojmowanej hermeneutyki. Chodzi tu mianowicie o zaznaczenie dystansu czasowego, który warunkuje hierarchię między egzegetą a tradycją egzegetyczną. Następnie o wydobycie konstruktywnego i obligatoryjnego zarazem udziału tradycji w procesie rozumienia. Wreszcie o priorytetowo inkryminowaną przez Bettiego, a bronioną przez Erazma dziejowość rozumienia i wyrastającą z niej świadomość historyczną ${ }^{121}$. W heideggerowsko-gadamerowskiej perspektywie można zatem dostrzec w Erazmie znamiona myśliciela, który ze stanowiska sceptycyzmu chrześcijańskiego istotnie przekraczał jedynie egzegetyczny wymiar rozumienia jako zracjonalizowanej metodycznie praktyki objaśniania tekstu.

Jeśli spojrzeć na wrażliwość hermeneutyczną Erazma w perspektywie określonych asocjacji pojęciowych - mam tu na myśli retoryczny sensus communis, zawsze dziejowo uwarunkowaną interpretatio oraz wymagającą krytycznej, a więc rozumnej weryfikacji auctoritas - to staje się ona jednym $\mathrm{z}$ relatywnie wczesnych ogniw długiej historii określonej wizji hermeneutyki, takiej mianowicie, która w centrum swojego zainteresowania umieszcza nie tylko reguły i kanony tzw. poprawnego rozumienia, a więc metodycznie zdyscyplinowaną umiejętność lektury tekstu, w znaczeniu klasycznych ars i $\tau \dot{\chi} \chi \nu \eta$, ale także niemało uwagi poświęca dziejowemu uwarunkowaniu i faktycznemu przebiegowi rozumienia oraz perswazyjno-prawdopodobnej specyfice wiedzy, której rozumienie dostarcza. To zatem typ hermeneutyki, która wyraża człowieczeństwo świadome swojej dziejowości i odpowiedzialne za własne słabości. Pomimo

120 Zob. E. Betti, Hermeneutyka jako ogólna metodologia nauk humanistycznych, przeł. M. Surma-Gawłowska, w: Myśl słaba - myśl mocna. Hermeneutyka włoska od połowy XX wieku. Antologia tekstów, wybór, przekład i opracowanie M. Surma-Gawłowska, A. Zawadzki, Kraków 2015, s. 26.

121 Zob. ibidem, s. 50. 
wspomnianych wyżej, teoriopoznawczych i metodycznych ograniczeń, epistemologia hermeneutyczna Erazma w ujęciu synchronicznym nie tylko przecząco odpowiada na słynne pytanie Bultmanna o możliwość bezzałożeniowej egzegezy ${ }^{122}$, ale nade wszystko jest bliska Gadamerowskiej, ontologicznej rehabilitacji przed-sądów (Vor-urteile), z tą jednak różnicą, że Erazm przede wszystkim podkreślał ich pozytywną poznawczo funkcję. Oskarżenia o spowalnianie lub nawet udaremnianie rozumienia pod wpływem przed-sądów i tradycji egzegetycznej, aczkolwiek obecne już w De servo arbitrio Lutra, Erazm uznawał jeszcze za bezpodstawne.

\section{Wybrana bibliografia}

Bader G., Assertio. Drei fortlaufende Lektüren zu Skepsis, Narrheit und Sünde bei Erasmus und Luther, Tübingen 1985.

Betti E., Hermeneutyka jako ogólna metodologia nauk humanistycznych, przeł. M. Surma-Gawłowska, w: Myśl słaba - myśl mocna. Hermeneutyka włoska od połowy XX wieku. Antologia tekstów, wybór, przekład i opracowanie M. SurmaGawłowska, A. Zawadzki, Kraków 2015, s. 21-68.

Boyle M. O'Rourke, Erasmus on Language and Method in Theology, Toronto 1977.

Bultmann R., Geschichte und Eschatologie, Tübingen 1964.

Bultmann R., Ist voraussetzungslose Exegese möglich?, w: idem, Glauben und Verstehen. Gesammelte Aufsätze, Bd. 3, Tübingen 1960, s. 142-150.

Christ-von Wedel Ch., Das Nichtwissen bei Erasmus von Rotterdam. Zum philosophischen und theologischen Erkennen in der geistigen Entwicklung eines christlichen Humanisten, Basel 1981.

Dilthey W., Der Aufbau der geschichtlichen Welt in den Geisteswissenschaften, Hg. von B. Groethuysen, Göttingen 1992.

Domański J., Erazm i filozofia. Studium o koncepcji filozofii Erazma z Rotterdamu, wyd. 2, Warszawa 2001.

Ebeling G., Evangelische Evangelienauslegung. Eine Untersuchung zu Luthers Hermeneutik, Tübingen 1991.

122 Zob. R. Bultmann, Ist voraussetzungslose Exegese möglich?, w: idem, Glauben und Verstehen. Gesammelte Aufsätze, Bd. 3, Tübingen 1960, s. 142, 148-150. 
Gadamer H.-G., Autorität und kritische Freiheit, w: idem, Über die Verborgenheit der Gesundheit. Aufsätze und Vorträge, Frankfurt am Main 1993, s. 149-158.

Gadamer H.-G., Prawda i metoda. Zarys hermeneutyki filozoficznej, przeł. B. Baran, Kraków 1993.

Harth D., Philologie und praktische Philosophie. Untersuchungen zum Sprach- und Traditionsverständnis des Erasmus von Rotterdam, München 1970.

Hauschild W.-D., Die Bewertung der Tradition in der lutheranischen Reformation, w: Kanon - Schrift - Tradition, Hg. von W. Pannenberg, Th. Schneider, Freiburg im Breisgau 1992, s. 195-231.

Heidegger M., Bycie i czas, przeł., przedmową i przypisami opatrzył B. Baran, Warszawa 1994.

Hermeneutik. Die Geschichte der abendländischen Textauslegung bis zur Gegenwart, Hg. von M. Böhl, W. Reinhard, P. Walter, Wien 2013.

Hermeneutik, Methodenlehre, Exegese. Zur Theorie der Interpretation in der Frühen Neuzeit, Hg. von G. Frank, S. Meier-Oeser, Stuttgart 2011.

Hoffmann M., Erkenntnis und Verwirklichung der wahren Theologie nach Erasmus von Rotterdam, Tübingen 1972.

Hoffmann M., Rhetoric and Theology. The Hermeneutics of Erasmus, Toronto 1994.

Kerlen D., Assertio. Die Entwicklung von Luthers theologischem Anspruch und der Streit mit Erasmus von Rotterdam, Wiesbaden 1976.

Kohls E.-W., Die Theologie des Erasmus, Bd. 1-2, Basel 1966.

Krüger F., Humanistische Evangelienauslegung. Desiderius Erasmus von Rotterdam als Ausleger der Evangelien in seinen Paraphrasen, Tübingen 1986.

Payne J.B., Toward the Hermeneutics of Erasmus, w: Scrinium Erasmianum, ed. J. Coppens, vol. 2, Leiden 1969, s. 14-49.

Pfeiffer R., Besprechung der von A. und H. Holborn herausgegebenen Ausgewählten Werke des Desiderius Erasmus Roterodamus, „Gnomon”, Bd. 12 (1936), s. 625-634.

Stróżewski W., Mała fenomenologia autorytetu, w: idem, W kręgu wartości, Kraków 1992, s. 27-32.

Stupperich R., Die theologische Neuorientierung des Erasmus in der Ratio seu methodus 1516/18, w: Actes du Congres Erasme, Amsterdam 1971, s. 148-158.

Stupperich R., Erasmus von Rotterdam und seine Welt, Berlin 1977.

Walter P., Theologie aus dem Geist der Rhetorik. Zur Schriftauslegung des Erasmus von Rotterdam, Mainz 1991. 